\title{
Changes in background aerosol composition in Finland during polluted and clean periods studied by TEM/EDX individual particle analysis
}

\author{
J. V. Niemi ${ }^{1}$, S. Saarikoski ${ }^{2}$, H. Tervahattu ${ }^{3}$, T. Mäkelä ${ }^{2}$, R. Hillamo ${ }^{2}$, H. Vehkamäki ${ }^{4}$, L. Sogacheva ${ }^{4}$, and \\ M. Kulmala ${ }^{4}$ \\ ${ }^{1}$ Department of Biological and Environmental Sciences, University of Helsinki, P.O. Box 27, FI-00014 Helsinki, Finland \\ ${ }^{2}$ Finnish Meteorological Institute, P.O. Box 503, FI-00101 Helsinki, Finland \\ ${ }^{3}$ Nordic Envicon Ltd., Koetilantie 3, FI-00790 Helsinki, Finland \\ ${ }^{4}$ Department of Physical Sciences, University of Helsinki, P.O. Box 64, FI-00014 Helsinki, Finland
}

Received: 6 June 2006 - Published in Atmos. Chem. Phys. Discuss.: 19 July 2006

Revised: 24 October 2006 - Accepted: 25 October 2006 - Published: 3 November 2006

\begin{abstract}
Aerosol samples were collected at a rural background site in southern Finland in May 2004 during pollution episode $\left(\mathrm{PM}_{1} \sim 16 \mu \mathrm{g} \mathrm{m}^{-3}\right.$, backward air mass trajectories from south-east), intermediate period $\left(\mathrm{PM}_{1} \sim 5 \mu \mathrm{g} \mathrm{m}^{-3}\right.$, backtrajectories from north-east) and clean period $\left(\mathrm{PM}_{1} \sim 2 \mu \mathrm{g} \mathrm{m}^{-3}\right.$, backtrajectories from northwest/north). The elemental composition, morphology and mixing state of individual aerosol particles in three size fractions were studied using transmission electron microscopy (TEM) coupled with energy dispersive X-ray (EDX) microanalyses. The TEM/EDX results were complemented with the size-segregated bulk chemical measurements of selected ions and organic and elemental carbon. Many of the particles in $\mathrm{PM}_{0.2-1}$ and $\mathrm{PM}_{1-3.3}$ size fractions were strongly internally mixed with $\mathrm{S}, \mathrm{C}$ and/or $\mathrm{N}$. The major particle types in $\mathrm{PM}_{0.2-1}$ samples were 1) soot and 2) (ammonium)sulphates and their mixtures with variable amounts of $\mathrm{C}, \mathrm{K}$, soot and/or other inclusions. Number proportions of those two particle groups in $\mathrm{PM}_{0.2-1}$ samples were $0-12 \%$ and $83-97 \%$, respectively. During the pollution episode, the proportion of Ca-rich particles was very high $(26-48 \%)$ in the $\mathrm{PM}_{1-3.3}$ and $\mathrm{PM}_{3.3-11}$ samples, while the $\mathrm{PM}_{0.2-1}$ and $\mathrm{PM}_{1-3.3}$ samples contained elevated proportions of silicates $(22-33 \%)$, metal oxides/hydroxides (1-9\%) and tar balls (1-4\%). These aerosols originated mainly from polluted areas of Eastern Europe, and some open biomass burning smoke was also brought by long-range transport. During the clean period, when air masses arrived from the Arctic Ocean, $\mathrm{PM}_{1-3.3}$ samples contained mainly sea salt particles (67-89\%) with a variable rate of $\mathrm{Cl}$ substitution (mainly by $\mathrm{NO}_{3}^{-}$). During the intermediate period, the $\mathrm{PM}_{1-3.3}$ sample contained
\end{abstract}

Correspondence to: J. V. Niemi

(jarkko.v.niemi@helsinki.fi) porous (sponge-like) Na-rich particles (35\%) with abundant $\mathrm{S}, \mathrm{K}$ and $\mathrm{O}$. They might originate from the burning of wood pulp wastes of paper industry. The proportion of biological particles and C-rich fragments (probably also biological origin) were highest in the $\mathrm{PM}_{3.3-11}$ samples $(0-81 \%$ and $0-22 \%$, respectively). The origin of different particle types and the effect of aging processes on particle composition and their hygroscopic and optical properties are discussed.

\section{Introduction}

The composition and mass concentrations of fine aerosol particles $\left(\mathrm{PM}_{2.5}\right)$ in clean background areas are strongly affected by long-range transport. During transport and aging, particles of different origin may change their properties due to coagulation and cloud processes as well as due to reactions with gases via various heterogeneous pathways. Thus, differences in sources and in meteorological conditions may strongly affect composition, mixing state, concentration and size of different particle types observed. These are essential factors related to the environmental and health impacts of aerosols, such as climate change and transport of nutrients, acids and toxic compounds (EMEP, 2001; IPCC, 2001; WHO, 2003; Chung and Seinfeld, 2005; Kanakidou et al., 2005; Sun and Ariya, 2006).

In Finland, anthropogenic emissions of particles and their precursor gases are low (EMEP, 2001, 2002), and most of the $\mathrm{PM}_{2.5}$ mass originates from long-range transport (Pakkanen et al., 2001; Vallius et al., 2003; Karppinen et al., 2004). In general, $\mathrm{PM}_{2.5}$ concentrations are also low, the annual mean $\mathrm{PM}_{2.5}$ concentration being only $5.8 \mu \mathrm{g} \mathrm{m}^{-3}$ at the rural station of Hyytiälä in southern Finland (Laakso et al., 2003).

Published by Copernicus GmbH on behalf of the European Geosciences Union. 
However, the particle concentration and composition vary strongly depending on meteorological conditions and aerosol source regions. High particle mass concentrations are observed when air masses arrive from polluted continental areas of Central and Eastern Europe, and low concentrations when air masses originate from the direction of the Atlantic and Arctic Oceans (Pakkanen et al., 2001; Ricard et al., 2002; Ruoho-Airola et al., 2004; Sogacheva et al., 2005; Tunved et al., 2005). Thus, clean background areas in Finland are especially favourable for investigation of the properties of aged, long-range transported aerosols with clearly different origins.

The composition of aerosol particles has been studied mostly with bulk chemical methods. Only a few studies on background aerosols in continental Europe have been performed using individual particle methods (Ebert et al., 2002, 2004; Held et al., 2002; Hinz et al., 2005), and these studies are especially sparse for Northern Europe (Bigg, 2001; Tervahattu et al., 2005). Individual particle methods provide information on chemical composition, sources, morphology and mixing state of particles, which cannot be observed with bulk chemical methods.

We examined the composition, morphology and mixing state of individual aerosol particles with the TEM/EDX method at a rural background site in southern Finland during polluted, intermediate and clean periods with different origins of particles. We describe major particle types observed in three size fractions $\left(\mathrm{PM}_{0.2-1}, \mathrm{PM}_{1-3.3}\right.$ and $\left.\mathrm{PM}_{3.3-11}\right)$ and investigate changes in their abundances, composition, mixing state and sources during different periods. To our knowledge, this is the first TEM/EDX study on background aerosols in continental Northern Europe. The results are compared with bulk chemical measurements performed during the same field campaign and also with individual particle studies for background aerosols conducted by other research groups. Furthermore, the effect of aging processes on particle composition and their hygroscopic and light absorption properties are discussed.

\section{Materials and methods}

\subsection{Aerosol sampling}

Aerosol samples were collected at the SMEAR II station (61.85 N, 24.28 E, 181 ma.s.l.) in Hyytiälä between 6 and 24 May 2004. The field station, located in a boreal pine forest, represents a clean background area in southern Finland (details in Kulmala et al., 2001).

Particle samples for bulk chemical analysis were collected with two identical virtual impactors (VIs) in parallel; one was used to collect samples for mass and ion analysis and the other for carbon analysis (Saarikoski et al., 2005). The VIs were modified versions of the original design of Loo and Cork (1988). They divide airborne particle matter into

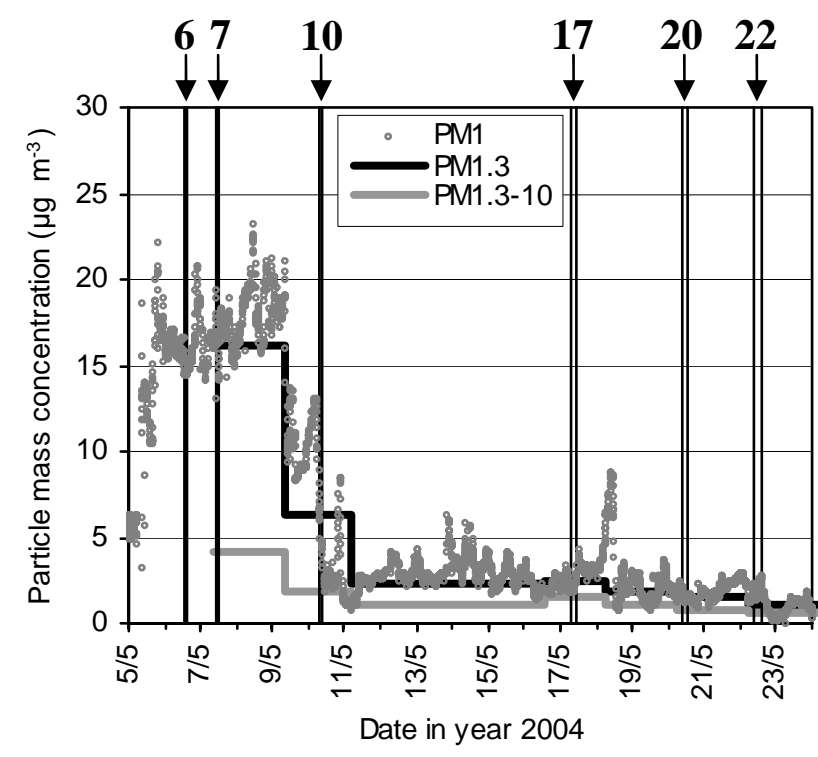

Fig. 1. Particle mass concentrations ( $\mathrm{PM}_{1}$ measured with ELPI, and $\mathrm{PM}_{1.3}$ and $\mathrm{PM}_{1.3-10}$ with VI) in Hyytiälä in May 2004. The six sampling periods with the Battelle impactor for TEM/EDX analysis are marked with vertical lines and arrows (sample numbers above).

two size fractions: $\mathrm{PM}_{1.3}$ and $\mathrm{PM}_{1.3-10}$. Collection substrates for mass and ion analysis were Teflon filters (diameter $47 \mathrm{~mm}$, pore size $3.0 \mu \mathrm{m}$, Millipore Fluoropore, Ireland), and for carbon analysis quartz fibre filters (diameter $47 \mathrm{~mm}$, Whatman QMA). In VI sampling for carbon analysis, denuders and back-up filters were used to minimize sampling artefacts. Sampling time was two days.

Particle samples for TEM/EDX individual particle analysis were collected with a Battelle-type impactor (model I1, PIXE International Corporation, Florida, USA), which is a modified version of the original design of Mitchell and Pilcher (1959). Cu TEM grids (400-mesh) with carboncoated Formvar films (Carbon Type-B, Ted Pella Inc., Redding, CA, USA) were placed on three impaction stages to collect particles in diameter ranges (cut-off sizes, $D_{50}$ ) of $0.2-1.0,1.0-3.3$ and $3.3-11 \mu \mathrm{m}$. The flow rate was $1 \mathrm{~L} / \mathrm{min}$. Sample collection times were 1-6 hours, depending on the particle concentrations during sampling. The TEM grids of six sampling periods (6 periods and 3 size fractions, total 18 TEM grids) were used for TEM/EDX analysis.

\subsection{Bulk chemical analysis}

VI samples were analysed chemically for elemental carbon (EC), organic carbon (OC), water-soluble ions and the sum of three monosaccharide anhydrides $\left(\sum \mathrm{MA}=\right.$ levoglucosan + galactosan + mannosan). EC and OC were measured with the thermal-optical carbon analyser (Sunset Laboratory Inc., Oregon, USA). Ion analysis was performed using two Dionex-500 ion chromatography systems, and the ions anal- 
Table 1. Arithmetic means of meteorological variables, $\mathrm{PM}_{1}$ mass concentrations and gas concentrations during sampling periods for TEM/EDX analysis (maximums shown in bold).

\begin{tabular}{|c|c|c|c|c|c|c|c|c|c|c|c|c|}
\hline $\begin{array}{l}\text { Sample } \\
\text { number }\end{array}$ & Date & $\begin{array}{l}\text { Time } \\
\text { UTC }\end{array}$ & $\begin{array}{c}\mathrm{T} \\
\left({ }^{\circ} \mathrm{C}\right)\end{array}$ & $\begin{array}{l}\mathrm{RH} \\
(\%)\end{array}$ & $\begin{array}{l}\text { Wind speed } \\
\quad\left(\mathrm{m} \mathrm{s}^{-1}\right)\end{array}$ & $\begin{array}{l}\text { Wind direction } \\
\text { (degree) }\end{array}$ & $\begin{array}{c}\mathrm{PM}_{1} \\
\left(\mu \mathrm{g} \mathrm{m}^{-3}\right)\end{array}$ & $\begin{array}{c}\mathrm{O}_{3} \\
(\mathrm{ppb})\end{array}$ & $\begin{array}{c}\mathrm{CO} \\
(\mathrm{ppm})\end{array}$ & $\begin{array}{l}\mathrm{SO}_{2} \\
(\mathrm{ppb})\end{array}$ & $\begin{array}{l}\mathrm{NO}_{2} \\
(\mathrm{ppb})\end{array}$ & $\begin{array}{l}\text { NO } \\
(\mathrm{ppb})\end{array}$ \\
\hline 6 & 06/05/2004 & $12: 33-14: 33$ & 23 & 29 & 2.8 & 151 & 14.9 & 62 & 160 & 0.63 & - & - \\
\hline 10 & $10 / 05 / 2004$ & $07: 53-09: 53$ & 8 & 82 & 4.1 & 35 & 4.5 & 27 & 148 & 0.06 & 2.1 & 0.22 \\
\hline 17 & $17 / 05 / 2004$ & $06: 58-10: 58$ & 9 & 36 & 3.6 & 278 & 2.2 & 40 & 135 & 0.12 & 0.9 & 0.07 \\
\hline 20 & 20/05/2004 & $08: 56-13: 26$ & 9 & 42 & 5.7 & 299 & 1.4 & 37 & 128 & 0.06 & 0.6 & 0.04 \\
\hline
\end{tabular}

ysed were $\mathrm{NO}_{3}^{-}, \mathrm{SO}_{4}^{2-}, \mathrm{Cl}^{-}$, methanesulphonate (MSA), oxalate, succinate, malonate, $\mathrm{Na}^{+}, \mathrm{NH}_{4}^{+}, \mathrm{K}^{+}, \mathrm{Mg}^{2+}$ and $\mathrm{Ca}^{2+}$. The details of ion and carbon analysis, and also the weighting of VI samples to calculate particle mass concentrations, are described in Saarikoski et al. (2005). ¿MA was determined by using a liquid chromatograph mass spectrometer (LC/MS; Agilent 1100 Series, Trap SL, Agilent Technologies, USA), and the analysis method is described in detail by Sillanpää et al. (2005).

\subsection{TEM/EDX individual particle analyses}

The morphology and elemental composition of individual aerosol particles were investigated using a Tecnai 12 transmission electron microscope (TEM) equipped with an EDAX energy dispersive X-ray (EDX) microanalyser. The TEM was operated on an accelerating voltage of $120 \mathrm{kV}$ and with a low beam current to minimize beam damage. Counting time for X-ray spectra was 20 live seconds. The minimum size of particles analyzed was $0.2 \mu \mathrm{m}$ (geometric diameter).

The elements analysed were with $\mathrm{Z}$ from $\mathrm{C}$ to $\mathrm{Pb}$, excluding $\mathrm{N}$. The $\mathrm{X}$-ray counts from carbon-Formvar coating (thickness listed as $\sim 60 \mathrm{~nm}$; contains abundant $\mathrm{C}$, some $\mathrm{O}$ and minor $\mathrm{Si}$ ) of TEM grids were estimated by analysing blank areas between particles. The net X-ray counts (= total counts - carbon-Formvar blank counts) of elements for each particle analysed were calculated, and their proportions were normalized to $100 \%$. Although the elemental results were semiquantitative, the accuracy is sufficient to identify different particle types and to compare the differences in elemental ratios of the same particle type in different samples (Pósfai et al., 2003; Ebert et al., 2004; Niemi et al., 2005b; Ro et al., 2005; Laskin et al., 2006). The strong vacuum $\left(\sim 10^{-7}\right.$ torr $)$ and beam exposure causes evaporation of semivolatile compounds from particles, and for that reason, water, ammonium nitrate and organic compounds with high vapour pressure were lost, as is typical in electron microscopy.

\subsection{Air quality and meteorological data}

Temperature, relative humidity $(\mathrm{RH})$, wind speed, wind direction and concentrations of gaseous components $\left(\mathrm{O}_{3}, \mathrm{CO}\right.$, $\mathrm{SO}_{2}, \mathrm{NO}_{2}$ and $\mathrm{NO}$ ) are recorded continuously at the SMEAR II station. Particle number concentrations and size distributions (from $29 \mathrm{~nm}$ to $10 \mu \mathrm{m}$ ) were monitored continuously during the field campaign (time resolution $1 \mathrm{~s}$, averaged to 10 min) with Electrical Low Pressure Impactor (Outdoor Air ELPI, Dekati Ltd, Tampere, Finland), and these results were used to calculate $\mathrm{PM}_{1}$ mass concentrations (equations described in Saarikoski et al., 2005). Backward air mass trajectories were produced using the HYbrid Single-Particle Lagrangian Integrated Trajectory (HYSPLIT4) model (Draxler and Rolph, 2003) with the Final Analyses (FNL) meteorological database at the NOAA Air Resources Laboratory's web server (Rolph, 2003). The Navy Aerosol Analysis and Prediction System (NAAPS) model results were used to determine the distribution of smoke aerosols from open biomass burning (http://www.nrlmry.navy.mil/aerosol/; the Naval Research Laboratory, Monterey, CA, USA).

\section{Results and discussion}

\subsection{Air quality and meteorology during sampling periods}

The particle mass concentrations were high at the beginning of the field campaign, and the first two samples (6 and 7) for TEM/EDX analysis were collected during that pollution episode (Fig. 1 and Table 1). The hourly PM $_{1}$ mass reached $22 \mu \mathrm{g} \mathrm{m}^{-3}$ during the episode, which is 5 times higher than the mean spring-time $\mathrm{PM}_{1}$ concentration in Hyytiälä (Laakso et al., 2003). During the episode, most of the $\mathrm{PM}_{10}$ mass was in the $\mathrm{PM}_{1.3}$ size fraction $(\sim 80 \%)$, which is a slightly higher proportion than in the rest of the field campaign $(\sim 60$ $70 \%)$. The concentrations of gaseous pollutants were also unusually high (Table 1$)$. The maximum value $(90 \mathrm{ppb})$ of $\mathrm{O}_{3}$ concentration in 2004 was also observed during this episode. Elevated particle mass and $\mathrm{O}_{3}$ concentrations were observed 


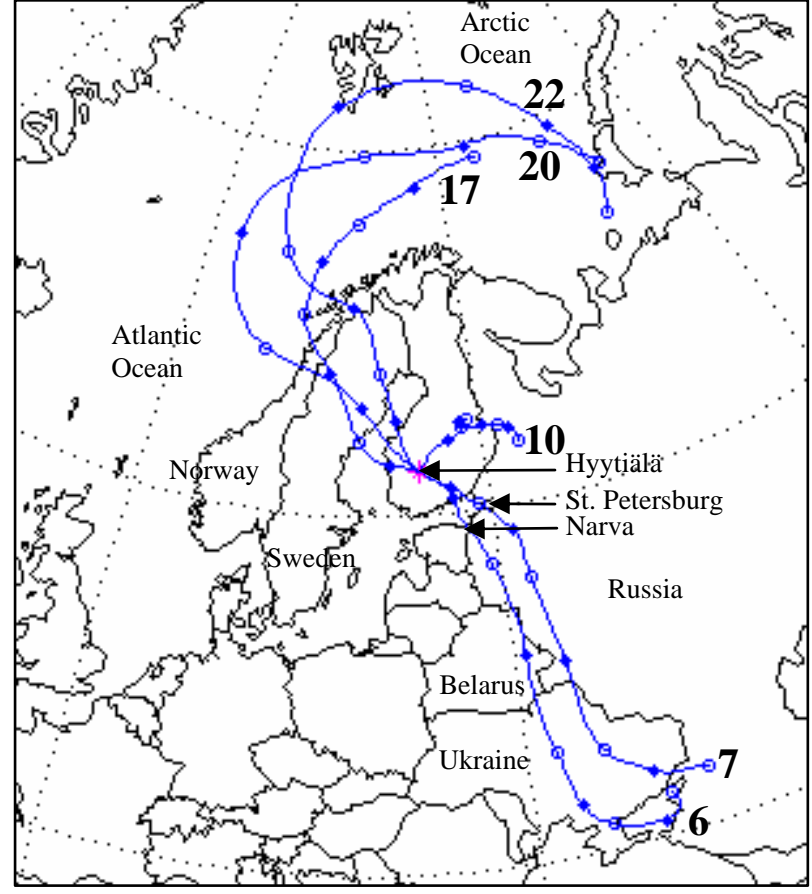

Fig. 2. Backward air mass trajectories arriving at $250 \mathrm{~m}$ level to Hyytiälä during the six sampling periods in May 2004. Date numbers (=sample numbers) of each trajectory are shown, and symbols represent 12-h intervals (total time $96 \mathrm{~h}$ ).

over larger areas in Finland between 4 and 9 May due to longrange transport of pollutants.

The backward trajectories show that during the pollution episode the continental air masses arrived from the direction of south-western Russia, Belarus and Ukraine (Fig. 2), which belong to typical source regions (polluted areas of Eastern and Central Europe) for aerosol particle episodes observed in Finland (Niemi et al., 2004, 2005a; Tervahattu et al., 2004; Sogacheva et al., 2005). During the episode, the weather was exceptionally warm (over $+20^{\circ} \mathrm{C}$, Table 1) compared with the mean temperature for May $\left(+9^{\circ} \mathrm{C}\right.$ in that region in $1971-$ 2001; Finnish Meteorological Institute). Only a few small showers occurred during the whole field campaign. The samples for TEM/EDX analysis were collected during the periods when there was no rain.

Sample 10 was collected just after or at the end of the pollution episode, and during that intermediate period (between the pollution episode and the clean period) the $\mathrm{PM}_{1}$ concentration was $4.5 \mu \mathrm{g} \mathrm{m}^{-3}$ (Fig. 1 and Table 1). The short backward trajectory of air masses originated from the north-east and curved towards the Arctic Ocean (Fig. 2). The last three samples (nos. 17-22) were collected during the clean period, when both $\mathrm{PM}_{1}$ mass (1.4-2.2 $\mu \mathrm{g} \mathrm{m}^{-3}$ ) and gaseous component concentrations were very low. Air masses arrived in Finland from the Arctic Ocean, passing over Norway and Sweden, which is a typical source sector for low particle mass

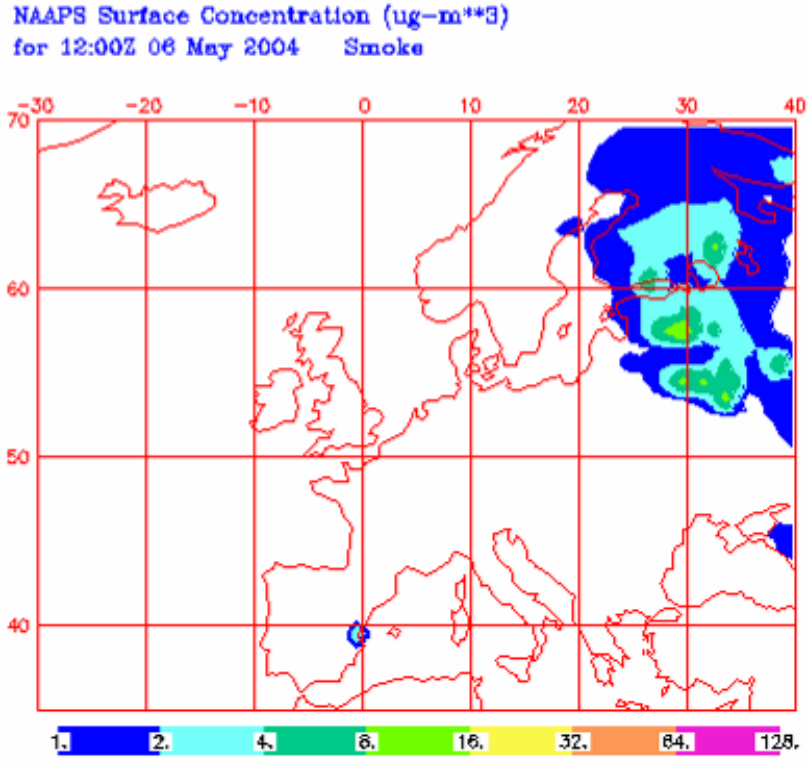

Fig. 3. NAAPS model results showing surface smoke concentrations in Europe at 12:00 (UTC) on 6 May 2004 (Naval Research Laboratory, Monterey, CA, USA, website at http://www.nrlmry. navy.mil/aerosol/).

concentrations (Sogacheva et al., 2005) due to minor anthropogenic emissions.

\subsection{Bulk chemical concentrations}

The $\mathrm{PM}_{1.3}$ and $\mathrm{PM}_{1.3-10}$ concentrations for particle mass, ions, $\sum \mathrm{MA}, \mathrm{EC}$ and $\mathrm{OC}$ are shown in Table 2. The results of bulk chemical analysis are not completely comparable with TEM/EDX results because of strong differences in the lengths of sampling periods (see difference in sampling periods with Battelle impactor for TEM/EDX and with VI for bulk chemical analysis in Fig. 1). However, the bulk chemical results give a good overview of particle composition during the sampling periods, with clearly different aerosol origins being apparent.

Most of the chemical components reached their maximum concentrations during the pollution episode (Table 2). During the clean period, the concentrations of $\mathrm{Na}^{+}, \mathrm{Cl}^{-}, \mathrm{Mg}^{2+}$ and MSA were elevated, which confirms the marine origin of the air mass. The concentrations of most chemical components were much higher in $\mathrm{PM}_{1.3}$ samples than in $\mathrm{PM}_{1.3-10}$ samples. However, $\mathrm{NO}_{3}^{-}, \mathrm{Cl}^{-}, \mathrm{Na}^{+}$(not during pollution episode), $\mathrm{Mg}^{2+}$ and $\mathrm{Ca}^{2+}$ were mostly present in the $\mathrm{PM}_{1.3-10}$ size fraction.

The main components in all $\mathrm{PM}_{1.3}$ samples were $\mathrm{OC}$, $\mathrm{SO}_{4}^{2-}, \mathrm{NH}_{4}^{+}$and EC, their total proportions in the $\mathrm{PM}_{1.3}$ mass being $73-83 \%$ (Table 2). The unidentified fraction was also quite high (20.0-25.5\%), and its major components were probably unanalysed elements related to OC (especially 
Table 2. Mass concentrations of total particle mass, ions, $\mathrm{OC}$ and $\mathrm{EC}$ in $\mathrm{PM}_{1.3}$ and $\mathrm{PM}_{1.3-10}$ size fractions during different sampling periods, and their relative proportions (\%) of total particle mass. Maximum values of each component in both size fractions are shown in bold.

\begin{tabular}{|c|c|c|c|c|c|c|c|c|c|c|}
\hline \multirow{3}{*}{$\begin{array}{l}\text { Start date } \\
\text { End date }\end{array}$} & \multirow{3}{*}{$\begin{array}{l}\text { Pollution episode } \\
07 / 05 \\
09 / 05 \\
\left(\mathrm{ng} \mathrm{m}^{-3}\right)\end{array}$} & \multirow{3}{*}{$\begin{array}{c}\text { Intermediate period } \\
09 / 05 \\
11 / 05 \\
\left(\mathrm{ng} \mathrm{m}^{-3}\right)\end{array}$} & \multicolumn{3}{|c|}{ Clean marine period } & \multirow{3}{*}{$\begin{array}{c}\text { Pollution episode } \\
07 / 05 \\
09 / 05 \\
(\%)\end{array}$} & \multirow{3}{*}{$\begin{array}{c}\text { Intermediate period } \\
09 / 05 \\
11 / 05 \\
(\%)\end{array}$} & \multicolumn{3}{|c|}{ Clean marine period } \\
\hline & & & $16 / 05$ & $20 / 05$ & $22 / 05$ & & & $16 / 05$ & $20 / 05$ & $22 / 05$ \\
\hline & & & $\begin{array}{c}18 / / 05 \\
\left(\mathrm{ng} \mathrm{m}^{-3}\right)\end{array}$ & $\begin{array}{c}22 / 05 \\
\left(\mathrm{ng} \mathrm{m}^{-3}\right)\end{array}$ & $\begin{array}{c}24 / 05 \\
\left(\mathrm{ng} \mathrm{m}^{-3}\right)\end{array}$ & & & $\begin{array}{c}18 / / 05 \\
(\%)\end{array}$ & $\begin{array}{c}22 / 05 \\
(\%)\end{array}$ & $\begin{array}{c}24 / 05 \\
(\%)\end{array}$ \\
\hline $\mathrm{PM}_{1.3}$ & & & & & & & & & & \\
\hline Mass & 16000 & 6300 & 2400 & 1500 & 1100 & & & & & \\
\hline $\mathrm{NO}_{3}^{-}$ & 42 & 14 & 24 & 24 & 6.6 & 0.26 & 0.23 & 1.0 & 1.6 & 0.58 \\
\hline $\mathrm{SO}_{4}^{2-}$ & 4600 & 1900 & 750 & 430 & 340 & 28.3 & 30.7 & 31.3 & 28.1 & 29.5 \\
\hline $\mathrm{Cl}^{-4}$ & 1.9 & 0.7 & 0.6 & 4.8 & 0.1 & 0.01 & 0.01 & 0.02 & 0.32 & 0.01 \\
\hline MSA & 21 & 22 & 110 & 96 & 33 & 0.13 & 0.34 & 4.55 & 6.3 & 2.91 \\
\hline Oxalate & 120 & 43 & 11 & 9.9 & 7 & 0.77 & 0.69 & 0.44 & 0.65 & 0.61 \\
\hline Succinate & 66 & 33 & 10 & 5.5 & 2.6 & 0.41 & 0.52 & 0.42 & 0.36 & 0.23 \\
\hline Malonate & 22 & 13 & 3.3 & 1.5 & 0.6 & 0.13 & 0.21 & 0.14 & 0.1 & 0.05 \\
\hline $\mathrm{Na}^{+}$ & 25 & 21 & 22 & 19 & 6.6 & 0.16 & 0.34 & 0.93 & 1.27 & 0.58 \\
\hline $\mathrm{NH}^{4+}$ & 1600 & 670 & 270 & 160 & 120 & 10.1 & 10.6 & 11.4 & 10.3 & 10.4 \\
\hline $\mathrm{K}^{+}$ & 150 & 42 & 18 & 8.8 & 4 & 0.9 & 0.66 & 0.74 & 0.57 & 0.35 \\
\hline $\mathrm{Mg}^{2+}$ & 2 & 2.2 & 2.2 & 3 & 0.9 & 0.01 & 0.04 & 0.09 & 0.2 & 0.08 \\
\hline $\mathrm{Ca}^{2+}$ & 8.8 & 4.2 & 4.2 & 1.5 & 0.1 & 0.05 & 0.07 & 0.17 & 0.1 & 0.01 \\
\hline$\sum \mathrm{MA}^{\mathrm{a}}$ & 15 & 8.3 & 1.7 & 3.4 & 1.1 & 0.09 & 0.13 & 0.07 & 0.23 & 0.1 \\
\hline EC & 520 & 160 & 100 & 76 & 100 & 3.25 & 2.49 & 4.26 & 4.99 & 8.74 \\
\hline $\mathrm{OC}^{b}$ & 5100 & 2100 & 730 & 460 & 400 & 31.4 & 33.4 & 30.1 & 30.3 & 34.5 \\
\hline Unidentified $^{c}$ & 4100 & 1400 & 480 & 340 & 170 & 25.5 & 21.5 & 20.0 & 22.4 & 15.3 \\
\hline $\begin{array}{l}\mathrm{PM}_{1.3-10} \\
\text { Mass }\end{array}$ & 4200 & 1000 & 1500 & 740 & 690 & & & & & \\
\hline $\mathrm{NO}_{3}^{-}$ & 370 & 110 & 110 & 41 & 15 & 8.72 & 6.03 & 7.36 & 5.58 & 2.2 \\
\hline $\mathrm{SO}_{4}^{2-}$ & 330 & 190 & 57 & 46 & 31 & 7.84 & 10 & 3.74 & 6.21 & 4.51 \\
\hline $\mathrm{Cl}^{-4}$ & 3.5 & 19 & 37 & 68 & 14 & 0.08 & 1.03 & 2.39 & 9.17 & 2.01 \\
\hline MSA & 0.1 & 1.7 & 4.3 & 5.1 & 1.9 & 0 & 0.09 & 0.28 & 0.69 & 0.28 \\
\hline Oxalate & 17 & 9.2 & 5.2 & 8.1 & 5.9 & 0.41 & 0.49 & 0.34 & 1.09 & 0.86 \\
\hline Succinate & 7.2 & 4.8 & 0 & 8.3 & 5.8 & 0.17 & 0.25 & 0 & 1.12 & 0.84 \\
\hline Malonate & 16.7 & 4.9 & 1.5 & 0.5 & 0 & 0.40 & 0.26 & 0.09 & 0.06 & 0 \\
\hline $\mathrm{Na}^{+}$ & 16 & 33 & 54 & 54 & 14 & 0.39 & 1.74 & 3.5 & 7.23 & 1.98 \\
\hline $\mathrm{NH}^{4+}$ & 78 & 37 & 12 & 8.2 & 8.9 & 1.84 & 1.95 & 0.79 & 1.1 & 1.29 \\
\hline $\mathrm{K}^{+}$ & 42 & 9.8 & 2.7 & 3.1 & 3.6 & 1.01 & 0.52 & 0.18 & 0.42 & 0.52 \\
\hline $\mathrm{Mg}^{2+}$ & 13 & 8 & 8.9 & 8.8 & 2.6 & 0.31 & 0.43 & 0.58 & 1.18 & 0.38 \\
\hline $\mathrm{Ca}^{2+}$ & 170 & 61 & 25 & 7 & 4.2 & 4.06 & 3.27 & 1.61 & 0.94 & 0.61 \\
\hline$\sum \mathrm{MA}^{a}$ & 0.5 & - & - & - & - & 0.01 & - & - & - & - \\
\hline EC & 90 & 84 & 69 & 72 & 100 & 2.15 & 4.46 & 4.53 & 9.65 & 14.5 \\
\hline $\mathrm{OC}^{b}$ & 1900 & 1600 & 1100 & 430 & 360 & 45.5 & 83.8 & 70.2 & 57.8 & 51.8 \\
\hline Unidentified $^{\mathrm{c}}$ & 1200 & -250 & 79 & 5 & 140 & 28.1 & -13.3 & 5.1 & 0.7 & 20.2 \\
\hline
\end{tabular}

a $\sum$ MA $=$ levoglucosan + galactosan + mannosan

$\mathrm{b}$ OC $=$ organic carbon + carbonate carbon

${ }^{\mathrm{c}}$ Unidentified $=$ particle mass $-\left(\mathrm{NO}_{3}^{-}+\mathrm{SO}_{4}^{2-}+\mathrm{Cl}^{-}+\mathrm{Na}^{+}+\mathrm{NH}^{4+}+\mathrm{K}^{+}+\mathrm{Mg}^{2+}+\mathrm{Ca}^{2+}+\mathrm{EC}+\mathrm{OC}\right)$. The one negative value probably results from an inaccuracy in $\mathrm{OC}$ analysis due to low particle concentrations.

$\mathrm{O}, \mathrm{H}$ and $\mathrm{N}$ ). During the pollution episode, the unidentified fraction was especially large (25.5\%), and it also contained silicates and metal oxides/hydroxides, as will be shown in TEM/EDX results. The weight percentage of $\mathrm{K}^{+}(0.90 \%)$ and oxalate $(0.77 \%)$ and the concentration of monosaccharide anhydride $\left(\sum \mathrm{MA}=15 \mathrm{ng} \mathrm{m}^{-3}\right)$ also reached their peak values during the pollution episode, indicating the presence of biomass burning aerosols (Andreae, 1983; Andreae et al., 1998; Simoneit et al., 1999; Sillanpää et al., 2005). However, their concentrations only rose slightly (especially $\sum M A$ ), which suggests that biomass burning was one source but not the main source of pollution episode aerosols. During a strong long-range transported wildfire smoke episode in Helsinki, Finland, the $\sum$ MA concentrations reached over 20 -fold higher values $\left(365 \mathrm{ng} \mathrm{m}^{-3}\right)$ in three-day $\mathrm{PM}_{2.5}$ samples (Sillanpää et al., 2005). Satellite observations (MODIS fire detections, Web Fire Mapper maps at http://maps.geog. umd.edu/) indicate that there were numerous fire areas, presumable agricultural field-burning and wildfires in Eastern Europe and especially in Russia, before and during the pol- 


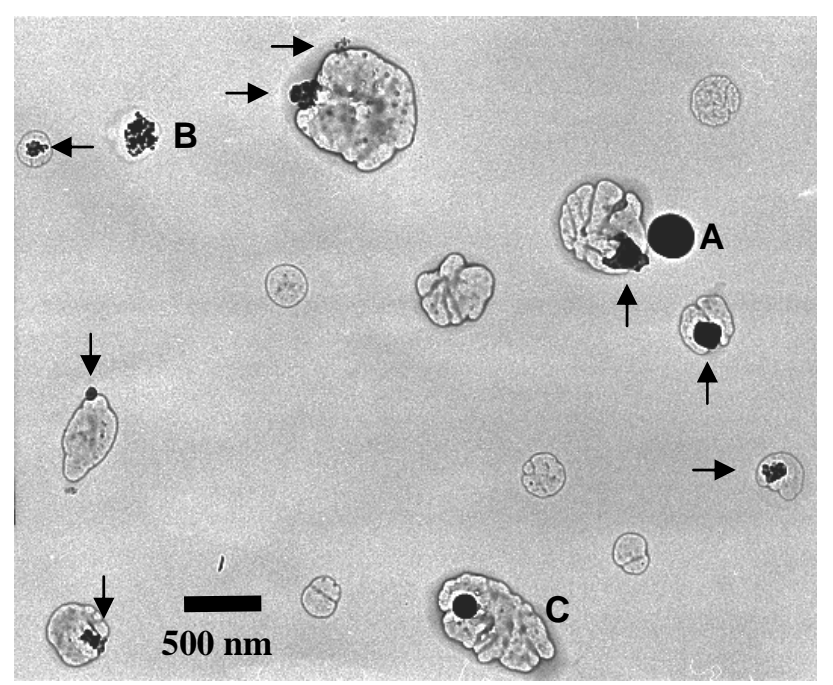

Fig. 4. TEM images of different particle types from $\mathrm{PM}_{0.2-1}$ sample 7 collected during the pollution episode; (a) tar ball, (b) soot and (c) Si-rich fly ash mixed with (ammonium)sulphates containing material. The rest of the particles were classified as "(ammonium)sulphates and their mixtures with $\mathrm{C}, \mathrm{K}$, soot (depicted with horizontal arrows) and/or with other inclusions (depicted with vertical arrows)".

lution episode. The trajectories (Fig. 2) and NAAPS model results (Fig. 3) indicate that some smoke aerosol from these fires arrived in Finland during this period.

The main components in all $\mathrm{PM}_{1.3-10}$ samples were $\mathrm{OC}$, $\mathrm{EC}, \mathrm{NO}_{3}^{-}$and $\mathrm{SO}_{4}^{2-}$ (Table 2). During the pollution episode, the weight percentages of $\mathrm{Ca}^{2+}(4.1 \%)$ and unidentified components $(28.1 \%)$ were especially high. During the clean marine period, $\mathrm{Na}^{+}$and $\mathrm{Cl}^{-}$weight percentages reached their highest proportions ( $7 \%$ and $9 \%$, respectively, in the 20 22/05 sample).

\subsection{Major particle types and their abundances by TEM/EDX}

The individual particles analysed were classified into 10 different particle groups based on their elemental composition, morphology, internal structure and susceptibility to damage by an electron beam. The particle groups and classification criteria are presented in Table 3. The relative abundances of each particle group in different size fractions are shown in Table 4 . The particles of the first three groups were mostly present in $\mathrm{PM}_{0.2-1}$ samples. These particle types were 1) tar balls, 2) soot and 3) (ammonium)sulphates and their mixtures with $\mathrm{C}, \mathrm{K}$ and/or different inclusions. The relative proportions of the remaining seven particle groups were usually highest in either $\mathrm{PM}_{1-3.3}$ or $\mathrm{PM}_{3.3-11}$ samples; 4) silicates, 5) metal oxides/hydroxides, 6) $\mathrm{Ca} / \mathrm{Mg}$ carbonates, sulphates and/or nitrates, 7) sea salt, 8) porous Na-rich particles, 9) biological particles and 10) C-rich fragments.

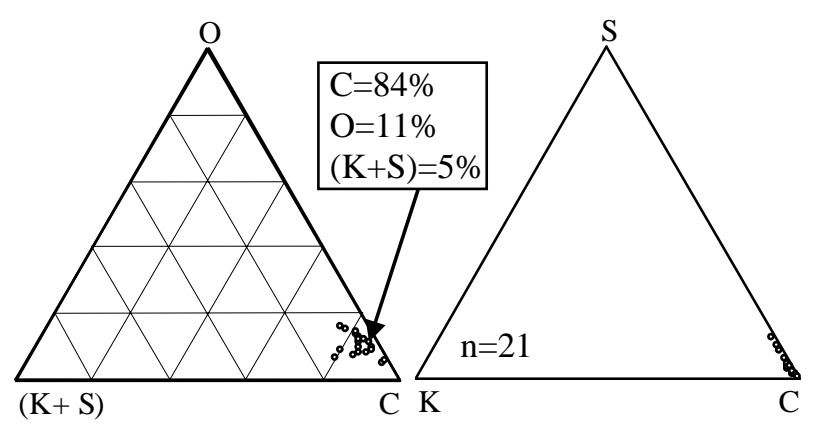

Fig. 5. Ternary diagrams of $\mathrm{C}-\mathrm{O}-(\mathrm{K}+\mathrm{S})$ and $\mathrm{C}-\mathrm{S}-\mathrm{K}$ ratios for tar balls collected during the pollution episode $\left(\mathrm{PM}_{0.2-1}\right.$ and $\mathrm{PM}_{1-3.3}$ samples 6-7). The X-ray count sum of the selected elements is normalized to $100 \%$, and an example of the elemental ratios is shown in the box.

\subsubsection{Tar balls}

During the pollution episode, $\mathrm{PM}_{0.2-1}$ and $\mathrm{PM}_{1-3.3}$ samples contained some (1-4\%) individual spherical C-rich particles that were very dark (electron-dense), amorphous and totally stable even in the presence of very strong electron beam (Fig. 4, particle A). Pósfai et al. (2003, 2004) named this kind of particles as tar balls, a distinct carbonaceous particle type from soot. Tar balls originate from biomass burning, especially during smouldering burning conditions (Pósfai et al., 2003, 2004; Chakrabarty et al., 2006). The relative proportion of the tar balls remained quite low or moderate (1$4 \%$ tar balls) during the pollution episode compared with the proportion observed at some other sites (Pósfai et al., 2003; Pósfai et al., 2004; Hand et al., 2005). The low proportion of tar balls is consistent with our bulk chemical results, indicating that biomass burning was one source but not the main source of the pollution episode.

The ternary diagrams in Fig. 5 show elemental ratios of tar balls in our samples. The most abundant elements were $\mathrm{C}$ (mean $84 \%$ of X-ray counts) and $\mathrm{O}$ (mean $11 \%$ ). Furthermore, all particles contained some $S$ (mean $4 \%$ ), and half of the particles contained minor amounts of $\mathrm{K}$ (mean of all analysed particles $1 \%$ ). In general, these elemental results are consistent with those of Pósfai et al. (2003, 2004) and Hand et al. (2005). However, they also observed $\mathrm{Cl}$ in some tar balls, and $\mathrm{S}$ was not present in all particles. Thus, the tar balls in our samples were likely transported from a distant source, probably from open fires in Eastern Europe (see Fig. 3), because $\mathrm{Cl}$ is absent and $\mathrm{S}$ is enriched in aged biomass smoke due to $\mathrm{Cl}$ depletion and accumulation of secondary products (Liu et al., 2000; Li et al., 2003b; Pósfai et al., 2003). The elemental results and visual inspection indicate that mixing with sulphate was very slight in tar balls compared with the mixing of soot with sulphate (Sect. 3.3.3). This observation is consistent with other studies (Pósfai et al., 2003, 2004; Hand et al., 2005). Tar balls scatter and absorb 
Table 3. Classification criteria for different particle groups.

\begin{tabular}{|c|c|c|}
\hline Particle group & Elemental characteristics * & $\begin{array}{l}\text { Typical morphology/internal structure } \\
\text { and beam sensitivity }\end{array}$ \\
\hline Tar balls & Abundant $\mathrm{C}$ with minor $\mathrm{S}$, often minor $\mathrm{K}$ & Individual particles with circular shape \\
\hline Soot & Abundant $\mathrm{C}$, often minor $\mathrm{S}, \mathrm{K}$ and/or $\mathrm{Si}$ & $\begin{array}{l}\text { Fractal-like agglomerates of circular par- } \\
\text { ticles }\end{array}$ \\
\hline $\begin{array}{l}\text { (Ammonium)sulphates and their } \\
\text { mixtures with } \mathrm{C}, \mathrm{K} \text { and/or differ- } \\
\text { ent inclusions }\end{array}$ & $\begin{array}{l}\mathrm{S} \text { with variable amounts of } \mathrm{C} \text { and/or (usu- } \\
\text { ally minor) } \mathrm{K}\end{array}$ & $\begin{array}{l}\text { Mostly circular shape, beam damage, } \\
\text { contains sometimes internally mixed soot } \\
\text { and other beam-resistant inclusions }\end{array}$ \\
\hline Silicates & $\begin{array}{l}\text { Abundant } \mathrm{Si} \text {, usually with } \mathrm{Al} \text {, variable } \\
\text { minor } \mathrm{Fe}, \mathrm{Ca}, \mathrm{K}, \mathrm{Mg}, \mathrm{Na}, \mathrm{Ti} \text {, and/or } \mathrm{S}\end{array}$ & $\begin{array}{l}\text { Irregular soil particles or circular fly ash } \\
\text { particles }\end{array}$ \\
\hline Metal oxides/hydroxides & Abundant $\mathrm{Mn}, \mathrm{Fe}, \mathrm{Zn}$ and/or $\mathrm{Pb}$ & $\begin{array}{l}\text { Irregular angular particles or circular fly } \\
\text { ash particles }\end{array}$ \\
\hline $\begin{array}{l}\mathrm{Ca} / \mathrm{Mg} \text { carbonates, sulphates } \\
\text { and/or nitrates }\end{array}$ & $\begin{array}{l}\text { Abundant } \mathrm{Ca} \text { with } \mathrm{C} \text { and/or } \mathrm{S} \text {, sometimes } \\
\text { with abundant } \mathrm{Mg} \text { and/or minor } \mathrm{Si}\end{array}$ & Mostly circular shape, sometimes angular \\
\hline Sea salt & $\begin{array}{l}\text { Abundant } \mathrm{Na} \text {, variable } \mathrm{Cl} \text { and } \mathrm{S} \text {, minor } \\
\mathrm{Mg}, \mathrm{K} \text { and } \mathrm{Ca}\end{array}$ & $\begin{array}{l}\text { Variable morphology; different angular } \\
\text { shapes or circular }\end{array}$ \\
\hline Porous Na-rich particles & Abundant $\mathrm{Na}$ with $\mathrm{S}$ and $\mathrm{K}$, no $\mathrm{Mg}$ and $\mathrm{Ca}$ & Sponge-like porous morphology \\
\hline Biological particles & Abundant $\mathrm{C}$, usually minor $\mathrm{K}$ and/or $\mathrm{P}$ & Variable morphology \\
\hline C-rich fragments & Abundant $\mathrm{C}$ & Angular shape, often thin \\
\hline
\end{tabular}

* Oxygen was present in practically all particles, and therefore, it is not shown in the element lists.

Table 4. Relative abundances (\%) of particles in different particle groups in three size fractions during the six sampling periods in May 2004. Maximum value of each particle group is shown with bold numbers. Int. per. = Intermediate period. The values in parentheses show the abundances of spherical/rounded particles.

\begin{tabular}{|c|c|c|c|c|c|c|c|c|c|c|c|c|c|c|c|c|c|c|}
\hline \multirow{3}{*}{$\begin{array}{l}\text { Size fraction } \\
\text { Sample number (= date) }\end{array}$} & \multicolumn{6}{|c|}{$0.2 \mu \mathrm{m}<\mathrm{Dp}<1 \mu \mathrm{m}$} & \multicolumn{6}{|c|}{$1 \mu \mathrm{m}<\mathrm{Dp}<3.3 \mu \mathrm{m}$} & \multicolumn{6}{|c|}{$3.3 \mu \mathrm{m}<\mathrm{Dp}<11 \mu \mathrm{m}$} \\
\hline & \multicolumn{2}{|c|}{$\begin{array}{l}\text { Pollution } \\
\text { episode }\end{array}$} & \multirow{2}{*}{$\begin{array}{c}\text { Int. per. } \\
10\end{array}$} & \multicolumn{3}{|c|}{$\begin{array}{c}\text { Clean marine } \\
\text { period }\end{array}$} & \multicolumn{2}{|c|}{$\begin{array}{l}\text { Pollution } \\
\text { episode }\end{array}$} & \multirow{2}{*}{$\begin{array}{c}\text { Int. per. } \\
10\end{array}$} & \multicolumn{3}{|c|}{$\begin{array}{c}\text { Clean marine } \\
\text { period }\end{array}$} & \multicolumn{2}{|c|}{$\begin{array}{l}\text { Pollution } \\
\text { episode }\end{array}$} & \multirow{2}{*}{$\begin{array}{c}\text { Int. per. } \\
10\end{array}$} & \multicolumn{3}{|c|}{$\begin{array}{l}\text { Clean marine } \\
\text { period }\end{array}$} \\
\hline & 6 & 7 & & 17 & 20 & 22 & 6 & 7 & & 17 & 20 & 22 & 6 & 7 & & 17 & 20 & 22 \\
\hline Tar balls & 1 & 2 & 0 & 0 & 0 & 0 & 4 & 4 & 2 & 0 & 0 & 0 & 0 & 0 & 0 & 0 & 0 & 0 \\
\hline Soot & 7 & 3 & 12 & 0 & 3 & 6 & 0 & 0 & 2 & 0 & 0 & 0 & 11 & 5 & 0 & 0 & 0 & 0 \\
\hline $\begin{array}{l}\text { (Ammonium)sulphates } \\
\text { and their mixtures with } \\
\mathrm{C}, \mathrm{K} \text { and/or different } \\
\text { inclusions }\end{array}$ & 84 & 87 & 83 & 95 & 97 & 93 & 9 & 14 & 5 & 6 & 2 & 15 & 0 & 0 & 0 & 5 & 0 & 0 \\
\hline Silicates & $4(1)$ & $4(2)$ & 0 & 3 & 0 & 0 & $22(1)$ & $26(7)$ & $14(2)$ & 17 & 2 & 5 & 32 & 33 & 0 & 53 & 5 & 6 \\
\hline Metal oxides/hydroxides & 1 & $4(2)$ & 0 & 1 & 0 & 1 & $4(1)$ & $9(1)$ & 0 & 0 & 0 & $3(1)$ & 5 & $5(5)$ & 11(6) & 0 & 0 & 3 \\
\hline $\begin{array}{l}\mathrm{Ca} / \mathrm{Mg} \text { carbonates, sul- } \\
\text { phates and/or nitrates }\end{array}$ & $1(1)$ & 0 & 0 & 0 & 0 & 0 & $48(22)$ & $39(27)$ & $3(3)$ & $10(6)$ & $2(2)$ & 1(1) & $26(21)$ & $38(29)$ & $6(6)$ & 0 & $5(5)$ & 0 \\
\hline Sea salt & 1 & 0 & 3 & 1 & 0 & 0 & 9 & 4 & 36 & 67 & 89 & 73 & 5 & 0 & 5 & 21 & 25 & 0 \\
\hline Porous Na-rich particles & 0 & 0 & 0 & 0 & 0 & 0 & 0 & 0 & 35 & 0 & 0 & 0 & 0 & 0 & 5 & 0 & 0 & 0 \\
\hline Biological particles & 0 & 0 & 0 & 0 & 0 & 0 & 0 & 0 & 2 & 0 & 2 & 0 & 21 & 14 & 50 & 0 & 55 & 81 \\
\hline C-rich fragments & 1 & 1 & 2 & 0 & 0 & 1 & 5 & 4 & 2 & 0 & 5 & 3 & 0 & 5 & 22 & 21 & 10 & 10 \\
\hline Number of analysed par- & 136 & 103 & 104 & 100 & 102 & 103 & 85 & 74 & 63 & 63 & 64 & 73 & 19 & 21 & 18 & 19 & 20 & 31 \\
\hline
\end{tabular}

light strongly, and they do not exhibit deliquescence but do uptake some water at $\sim 83 \% \mathrm{RH}$ and may dissolve at higher
RH (Hand et al., 2005). Thus, they may play an important role in regional haze and climate forcing. 

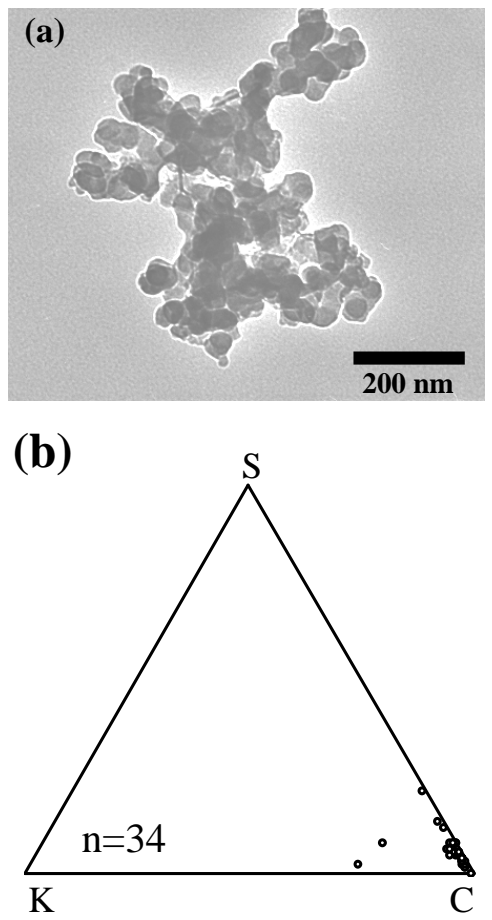

Fig. 6. TEM image of (a) soot particle and (b) C-S-K ternary diagram for soot particles from all $\mathrm{PM}_{0.2-1}$ samples.

\subsubsection{Soot particles}

Soot particles were present almost in all $\mathrm{PM}_{0.2-1}$ samples (0-12\%; Table 4). Furthermore, several soot particles were strongly mixed with beam-sensitive, S-containing material, and they are described in next section (not included in the above-mentioned percentage value). Soot particles are formed by numerous spherical carbon particles (diameter $\sim 20-50 \mathrm{~nm}$ ), and the morphology of soot varies from short chains to complex chain-agglomerates depending on burning conditions (Fig. 6a, Pósfai et al., 2003; Kocbach et al., 2005). In addition to $C$ and $O$ most soot particles contained also minor amounts of S and K (Fig. 6b) and some particles contained small quantities of Si. These are typical minor elements in soot (Kocbach et al., 2005). Soot particles are the most important light-absorbing component of aerosols (IPCC, 2001), and the mixing with hygroscopic chemical components during transport strongly affects their climatic effects, as discussed below.

\subsection{3 (Ammonium)sulphates and their mixtures with $\mathrm{C}, \mathrm{K}$ and/or different inclusions}

Most particles (83-97\%, Table 4) in $\mathrm{PM}_{0.2-1}$ samples were damaged easily under beam exposure. These particles contained $\mathrm{S}$ with variable amounts of $\mathrm{C}, \mathrm{O}$ and (usually minor) K. Sometimes minor amounts of other elements $(\mathrm{Mg}$,

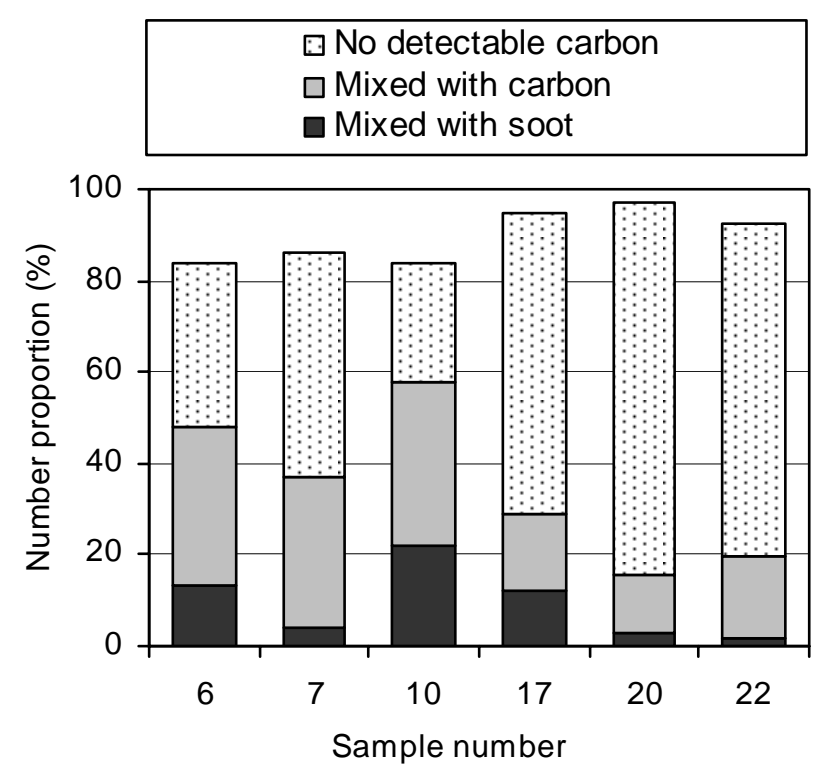

Fig. 7. Proportions of different subgroups of (ammonium)sulphates containing beam-sensitive particles in $\mathrm{PM}_{0.2-1}$ samples.

$\mathrm{Ca}, \mathrm{Na}, \mathrm{Si}$ and $\mathrm{Al}$; during pollution episode also $\mathrm{Pb}, \mathrm{Zn}, \mathrm{V}$ and $\mathrm{Ni}$ ) were also detected. The sulphur in these particles was probably present mainly as ammonium sulphate salts (e.g. $\left.\left.\left(\mathrm{NH}_{4}\right)_{2} \mathrm{SO}_{4},\left(\mathrm{NH}_{4}\right) \mathrm{HSO}_{4}\right),\left(\mathrm{NH}_{4}\right)_{3} \mathrm{H}\left(\mathrm{SO}_{4}\right)_{2}\right)$ because the particles did not have a satellite droplet ring(s) around them, which is characteristic of such acid sulphates as $\mathrm{H}_{2} \mathrm{SO}_{4}$ particles (Pósfai and Molnár, 2000; Kojima et al., 2004, 2005). The high concentrations of $\mathrm{SO}_{4}^{2-}$ and $\mathrm{NH}_{4}^{+}$measured by ion chromatography (Table 2) also support the dominance of ammonium sulphate salts. Because ammonium cannot be detected with EDX, we decided to name S-containing components of these particle as (ammonium)sulphates. Furthermore, some of these beam-sensitive particles contained beam-resistant soot agglomerates and some particles contained also other beam-resistant dark (= electron-opaque) inclusions without clear morphological characteristics (Fig. 4). The origin of the dark inclusions remained unclear. They might contain material from particles of biological origin and/or material from burning sources such as collapsed tar balls or soot.

More detailed classification of these (ammonium)sulphates containing beam-sensitive particles is challenging and partly artificial (see also referee comments for this article from the web pages of this journal) because the variations in elemental ratios of $\mathrm{S}, \mathrm{C}$ and $\mathrm{K}$ were continuums and because the size and morphology of soot inclusions and other non-recognizable beam-resistant inclusions varied strongly. However, particles were coarsely divided into three subgroups to illustrate some characteristics of this largest particle group (83-97\%) of $\mathrm{PM}_{0.2-1}$ samples. The subgroups are a) (ammonium)sulphates mixed 

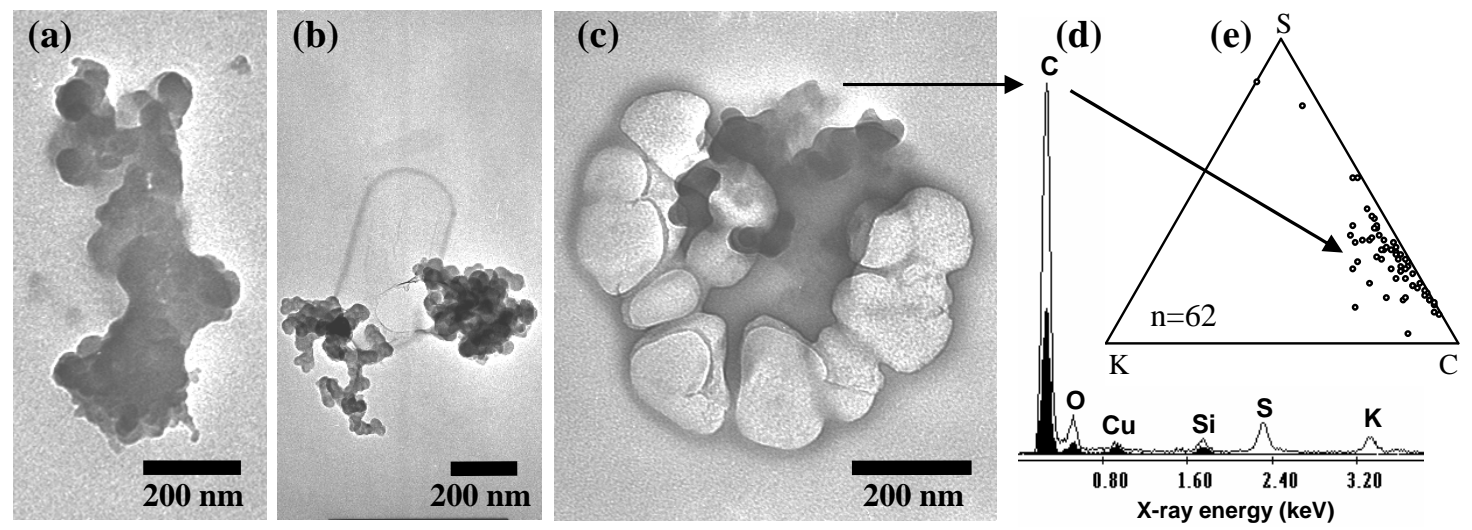

Fig. 8. TEM images of (a) mixed soot/sulphate-containing particle, (b-c) mixed soot/sulphate-containing particles after intentional strong beam exposure, (d) X-ray spectrum for the soot/sulphate-containing particle (background spectrum from TEM grid substrate is depicted in black) and (e) C-S-K ternary diagram for mixed soot/sulphate-containing particles from all $\mathrm{PM}_{0.2-1}$ samples.

with recognizable soot, b) (ammonium)sulphates mixed with carbon and c) (ammonium)sulphates without detectable carbon. The elevated total $\mathrm{C}$ peak to background $\mathrm{C}$ peak ratios $(>1.3)$ were considered rough estimates of the presence of detectable carbon. The proportions of each subgroup in $\mathrm{PM}_{0.2-1}$ samples are shown in Fig. 7 and characteristics of particles are discussed below.

The shape of particles in "(ammonium)sulphates mixed with soot" subgroup varied strongly (Fig. 8a-c and Fig. 4). The morphology of several soot aggregates was collapsed and compact, which suggests that they have been in contact with water during transport (Zuberi et al., 2005). In some of these particles, soot had almost totally lost its characteristic morphology. The C-S-K ternary diagrams in Fig. 6b and 8e show the marked difference in $\mathrm{S}$ content of soot and internally mixed soot/sulphate particles (see also example spectrum in Fig. 8d). The proportions of internally mixed soot/sulphate particles were $2-22 \%$ in $\mathrm{PM}_{0.2-1}$ samples (Fig. 7), which are somewhat higher proportions compared to those of soot $\left(0-12 \%\right.$; Table 4). Thus, in $\mathrm{PM}_{0.2-1}$ samples, $\sim 60 \%$ (range $25-100 \%$ ) of soot was internally mixed with (ammonium)sulphates. Because some particles in (ammonium)sulphates "mixed with carbon" and "without detectable carbon" subgroups might also contain unidentifiable soot particles (dark inclusions without clear morphological characteristics), the proportions for internally mixed soot/sulphate particles should be considered as minimum estimates. The strong internal mixing of soot is in line with other studies performed in clean background areas, far from soot emission sources (Pósfai et al., 1999; Hasegawa and Ohta, 2002; Li et al., 2003a; Okada et al., 2005). While freshly emitted soot is extremely hydrophobic, the aging processes such as coagulation, condensation and chemical reactions cause soot to become rapidly (in polluted conditions during less than a few hours; Johnson, 2005) more hydrophilic (Zuberi et al., 2005). The internal mixing of soot with sulphate (as well with hygroscopic OC and nitrate) particles strengthens soot's light absorption properties, increasing the direct radiative forcing (Chung and Seinfeld, 2005; Schnaiter et al., 2005). However, the total effect of soot on radiation balance of the Earth is still difficult to estimate accurately because the aging of soot decreases its poorly known surface area (see van Poppel et al., 2005 based on 3-dimensional TEM images), shortens its residence time in the atmosphere due to more efficient wet deposition and enables soot to act as cloud condensation nuclei (CCN) (Liu et al., 2005; Zuberi et al., 2005).

The (ammonium)sulphates without recognizable soot were divided as particles "mixed with carbon" (13-36\%, Fig. 7) and "without detectable carbon" (26-81\%). Although the particle size distributions were fairly similar in all $\mathrm{PM}_{0.2-1}$ samples, there were clear differences between samples in the proportion of particles with and without detectable C (Fig. 7). The results indicate that there were large amounts of particles with internally mixed (ammonium)sulphates and (vacuum-resistant) carbon; their proportions were higher during the pollution episode and the intermediate period (33-36\% in samples 6-10) than in the clean, marine period (13-17\% in samples 17-22). The presence of internally mixed (ammonium)sulphates and carbon is in line with other recent studies, conducted in various continental environments (Lee et al., 2002; Pósfai et al., 2003; Dall'Osto et al., 2004; Tervahattu et al., 2005; Zhang et al., 2005). Pósfai and Molnár (2000) also show some visual evidence (TEM images) that (ammonium)sulphates are more strongly mixed with carbon (thick coating residuals) in polluted continental samples than in clean marine samples. However, it is still insufficiently known what kind of mixtures ammonium sulphate salts and carbonaceous components form in the atmosphere, how commonly these mixed particles exist and how strongly the changes in the mixing state affect the properties of the particles (e.g. impact on hygroscopic growth and 


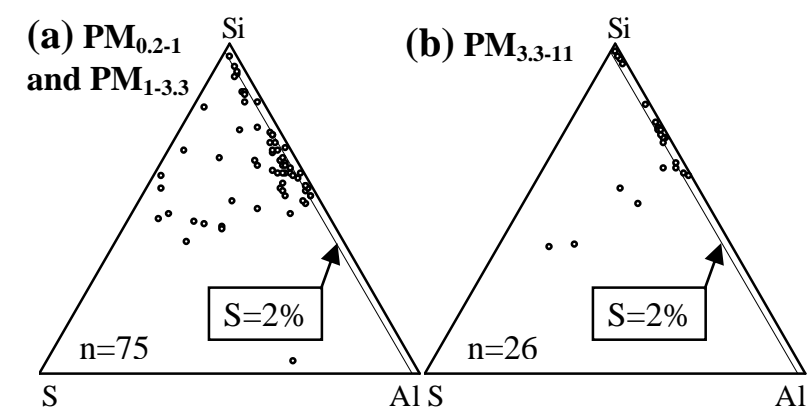

Fig. 9. Ternary diagrams of Al-Si-S ratios for silicates from all (a) $\mathrm{PM}_{0.2-1}$ and $\mathrm{PM}_{1-3.3}$ samples and (b) $\mathrm{PM}_{3.3-11}$ samples.

reactions with gases) (Kanakidou et al., 2005; Donaldson and Vaida, 2006; Sun and Ariya, 2006).

The proportion of $\mathrm{K}$ varied strongly in (ammonium)sulphates containing particles. The high proportion of $\mathrm{K}$ is typical of aerosols originating from biomass burning. The proportion of K-rich particles (= proportion of $\mathrm{K}$ higher compared to proportions of $\mathrm{C}$ or $\mathrm{S}$ ) was $0-9 \%$ in $\mathrm{PM}_{0.2-1}$ samples (proportions are not shown and separated from (ammonium)sulphates containing particles in Fig. 7). The highest proportion (9\%) of K-rich particles was observed in sample 17 during the clean, marine period. However, this might be a coincidence due to the relatively small number of particles analysed. There were slight differences between samples when K/S ratios were calculated for all S-C-Kcontaining particle groups, including particles described in this section ((ammonium)sulphates and their mixtures with $\mathrm{C}, \mathrm{K}$ and/or different inclusions) as well in previous sections (tar balls and soot particles); the median K/S values were slightly higher during the pollution episode (0.21 and 0.16 for samples 6 and 7, respectively) and during the intermediate period ( 0.12 for sample 10$)$ than during the clean, marine period $(0.12,0.08$ and 0.05 for samples 17,20 and 22, respectively). This indicates again the presence of some biomassburning aerosols during the pollution episode. In sample 6, emissions from oil-shale-burning industrial areas, located in Narva (see Fig. 2) and Slantsy ( $\sim 25 \mathrm{~km}$ south of Narva), may also have increased the K/S ratio because they contain a substantial amount of $\mathrm{K}$ in the submicron size range (Häsänen et al., 1997; Tervahattu et al., 2004).

\subsubsection{Silicates and metal oxides/hydroxides}

Si-O-rich particles with variable amounts of other typical elements of the Earth's crust ( $\mathrm{Al}$ and minor $\mathrm{Fe}, \mathrm{Ca}, \mathrm{K}$, $\mathrm{Mg}, \mathrm{Na}$ and/or Ti depending on the mineralogy of particles) were classified as silicates, while particles in the "metal oxides/hydroxides" group were mostly Fe-rich, and a few particles also contained abundant $\mathrm{Zn}, \mathrm{Mn}$ and/or $\mathrm{Pb}$. The shape of silicates and metal oxides/hydroxides was usually angular, but a few spherical fly ash particles were also observed.
The proportions of both angular and spherical silicates and metal oxides/hydroxides were especially high during the pollution episode (Table 4), and $\mathrm{Pb}$-containing particles were observed only during this period. When all particles with at least minor (detectable) $\mathrm{Pb}$ were counted from all particle groups (some $\mathrm{S}-\mathrm{K}-\mathrm{C}$-rich particles also contained $\mathrm{Pb}$ as mentioned above), the proportions of $\mathrm{Pb}$-containing particles were $3-7 \%$ in $\mathrm{PM}_{1-3.3}$ and $\mathrm{PM}_{0.2-1}$ samples. These elevated proportions of heavy metals and fly ash particles indicate that polluted air masses from Eastern Europe carried aerosols from metal industry and/or fossil fuel burning.

The silicates contained variable amounts of $S$, and the $S$ proportions were clearly higher in $\mathrm{PM}_{1-3.3}$ samples than in $\mathrm{PM}_{3.3-11}$ samples (Fig. 9a and b). The proportion of silicates with a $\mathrm{S} /(\mathrm{Si}+\mathrm{Al}+\mathrm{S})$ ratio $>0.02$ (see $\mathrm{S}=2 \%$ line in Fig. $9 \mathrm{a}$ and b) was $84 \%$ for $\mathrm{PM}_{0.2-1}$ and $\mathrm{PM}_{1-3.3}$ (merged) samples, and only $23 \%$ for $\mathrm{PM}_{3.3-11}$ samples. This difference in $\mathrm{S}$ content probably results from the accumulation of sulphate on the surfaces of silicates during transport due to condensation and coagulation of S-containing species. The silicates in $\mathrm{PM}_{1-3.3}$ samples have a higher surface area to volume ratio and a longer residence time in the atmosphere (due to slow gravitational removal) than larger silicate particles in $\mathrm{PM}_{3.3-11}$ samples, which probably explains the difference in $\mathrm{S}$ proportion. The sulphate accumulation on the surface of the silicates increases their hygroscopicity and enables these internally mixed particles to act as $\mathrm{CCN}$ at high supersaturation.

\subsection{5 $\mathrm{Ca} / \mathrm{Mg}$ carbonates, sulphates and/or nitrates}

Ca-O-rich particles with variable $\mathrm{Mg}, \mathrm{C}, \mathrm{S}$ and $\mathrm{Si}$ were classified as Ca-rich particles (see example spectra in Figs. 10a and $\mathrm{b}$ ), and this group was named as " $\mathrm{Ca} / \mathrm{Mg}$ carbonates, sulphates and/or nitrates". Furthermore, some of these particles contained minor amounts of other elements such as $\mathrm{Al}, \mathrm{K}$, $\mathrm{P}$ and $\mathrm{Fe}$. The shape of the $\mathrm{Ca}$-rich particles varied from angular to completely rounded (Fig. 10a and b). The ratios of major elements in Ca-rich particles for different $\mathrm{PM}_{1-3.3}$ samples are shown in ternary diagrams (Fig. 10c). The dominance of $\mathrm{Ca}$ and $\mathrm{C}$, with abundant $\mathrm{Mg}$ and/or $\mathrm{Si}$ in a few particles, suggests the presence of $\mathrm{Ca}$ - and $\mathrm{Ca}-\mathrm{Mg}$-carbonates (e.g. calcite $\mathrm{CaCO}_{3}$ and dolomite $\left.\mathrm{CaMg}\left(\mathrm{CO}_{3}\right)_{2}\right)$ and their (minor) mixtures with silicates. Furthermore, $\mathrm{S}$ was detected in all particles, which indicates that they contained sulphate. Nitrate was also probably present because the proportions of $\mathrm{C}, \mathrm{S}$ and $\mathrm{Si}$ were very low in some particles, and only $\mathrm{Ca}$ and $\mathrm{O}$ were detected. However, only very weak $\mathrm{N}$ peaks were observed in X-ray spectra due to strong peak overlap of $\mathrm{C}$ and $\mathrm{O}$ with $\mathrm{N}$ and due to the deep gap in transmissions characteristic of the EDX window for the K $\alpha$ line of $\mathrm{N}$.

The relative number of Ca-rich particles was very high during the pollution episode (samples 6-7), especially in $\mathrm{PM}_{1-3.3}$ samples (39-48\%; Table 4) but also in $\mathrm{PM}_{3.3-11}$ samples (26-28\%). During other sampling periods, these 
size fractions contained $\leq 10 \%$ Ca-rich particles, and in $\mathrm{PM}_{0.2-1}$ samples there were practically no Ca-rich particles. During the pollution episode, air masses passed over Estonian and Russian oil-shale-burning industrial areas located in Narva and Slantsy (sample 6, see Fig. 2), and over the region of St. Petersburg (sample 7). These regions belong to the strongest source areas of aerosols and $\mathrm{Ca}$ in Northern Europe (Häsänen et al., 1997; Lee and Pacyna, 1999; Jalkanen et al., 2000; EMEP, 2002), and thus, the pollution episode Ca-rich particles might originate mainly from these areas. A more detailed source identification of Ca-rich particles is difficult because they can originate from various sources, including fossil fuel and biomass burning, cement and metal industries, soil dust and marine sources (Hoornaert et al., 1996; Lee and Pacyna, 1999; Li et al., 2003b). However, the relative amount of $\mathrm{Mg}$ and $\mathrm{Si}$ in Ca-rich particles was highest in sample 6 and lowest in samples 10-22 (see Fig. 10c), which can be explained by the differences in their origin. For instance, the proportion of particles with $\mathrm{Ca} /(\mathrm{Ca}+\mathrm{Mg}+\mathrm{Si})>80 \%$ (see $\mathrm{Si}$ $\mathrm{Ca}-\mathrm{Mg}$ ternary diagrams in Fig. 10c) were $24 \%$ for sample 6, 59\% for sample 7 and $70 \%$ for samples 10-22. The high proportion of Ca-rich particles with only minor $\mathrm{Si}$ and/or $\mathrm{Mg}$ in samples 10-22 might indicate a stronger impact of such marine sources as fractional recrystallization of sea salt particles or marine organisms (e.g. coccoliths) (Andreae et al., 1986).

The substitution of $\mathrm{CO}_{3}^{2-}$ by $\mathrm{SO}_{4}^{2-}$ and $\mathrm{NO}_{3}^{-}$is typical of $\mathrm{Ca} / \mathrm{Mg}$ carbonates in the atmosphere due to reactions with $\mathrm{SO}_{2}$ and $\mathrm{HNO}_{3}$ (Song and Carmichael, 1999; Al-Hosney and Grassian, 2005; Laskin et al., 2005b). These conversion products are highly hygroscopic (e.g. deliquescence RH for amorphous $\mathrm{Ca}\left(\mathrm{NO}_{3}\right)_{2}$ particles is only $\sim 13 \%$, Tang and Fung, 1997). In $\mathrm{PM}_{1-3.3}$ samples, several rounded Ca-rich particles seemed to be very thin (light contrast in TEM images), indicating that they have been in liquid form during the impaction on TEM grids. During the collection of samples $6-7$, the RH was only $30-31 \%$, which shows that also mixed $\mathrm{Ca} / \mathrm{Mg}$ carbonates/sulphates/nitrates may occur at least partly in liquid form even at very low RH. This is consistent with the results of recent laboratory studies with environmental SEM (with adjustable $\mathrm{RH}$ ) for Ca-rich particles collected from various environments (Laskin et al., 2005a, 2005b). The substitution of $\mathrm{CO}_{3}^{-}$with $\mathrm{SO}_{4}^{2-}$ and $\mathrm{NO}_{3}^{-}$from $\mathrm{Ca} / \mathrm{Mg}$-rich particles may change optical and $\mathrm{CCN}$ properties as well as residence time in the atmosphere. Furthermore, these reactions provide a sink for $\mathrm{SO}_{2}$ and $\mathrm{HNO}_{3}$ and release $\mathrm{CO}_{2}$.

\subsubsection{Sea salt and porous Na-rich particles}

The morphology and composition of sea salt particles varied strongly. They contained abundant $\mathrm{Na}$ and variable amounts of $\mathrm{Cl}$ and/or $\mathrm{S}$ and $\mathrm{O}$, depending on the rate of $\mathrm{Cl}$ substitution, as well as minor amounts of $\mathrm{Mg}, \mathrm{Ca}$ and $\mathrm{K}$. There were cubic, angular and rounded particles, and some of them
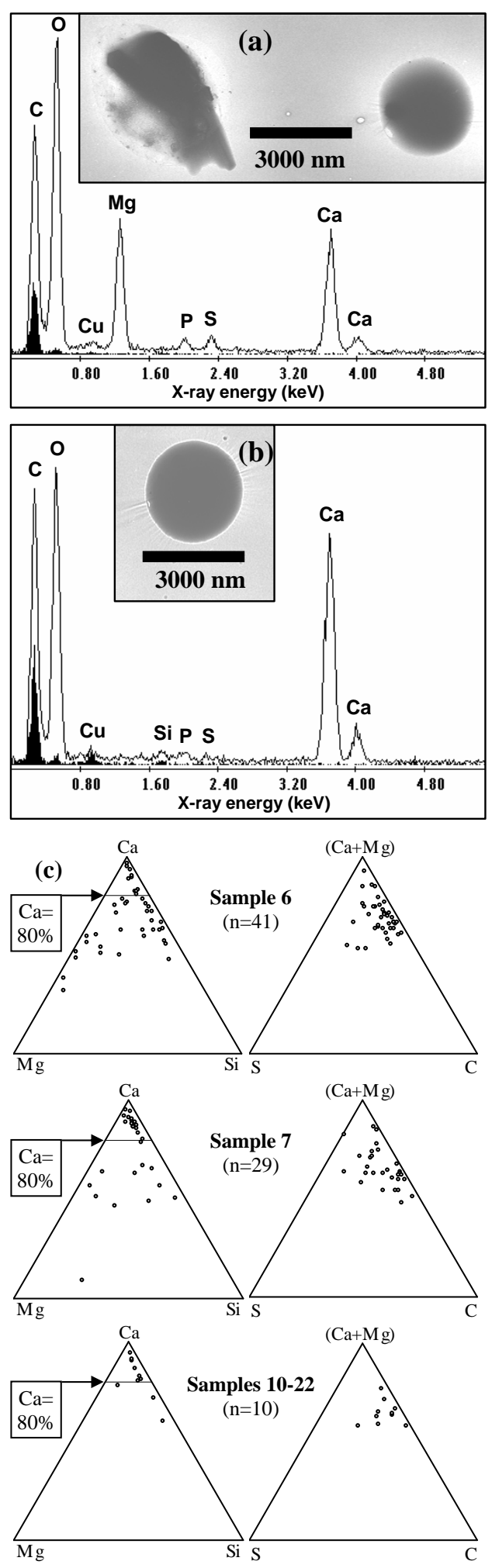

Fig. 10. TEM images of Ca-rich particles (a) with abundant $\mathrm{Mg}$ and (b) without $\mathrm{Mg}$ together with their X-ray spectra (from the spherical particles), and (c) ternary diagrams of Si-Ca-Mg and C-(Ca+Mg)-S ratios for $\mathrm{Ca}$-rich particles from selected $\mathrm{PM}_{1-3.3}$ samples. 


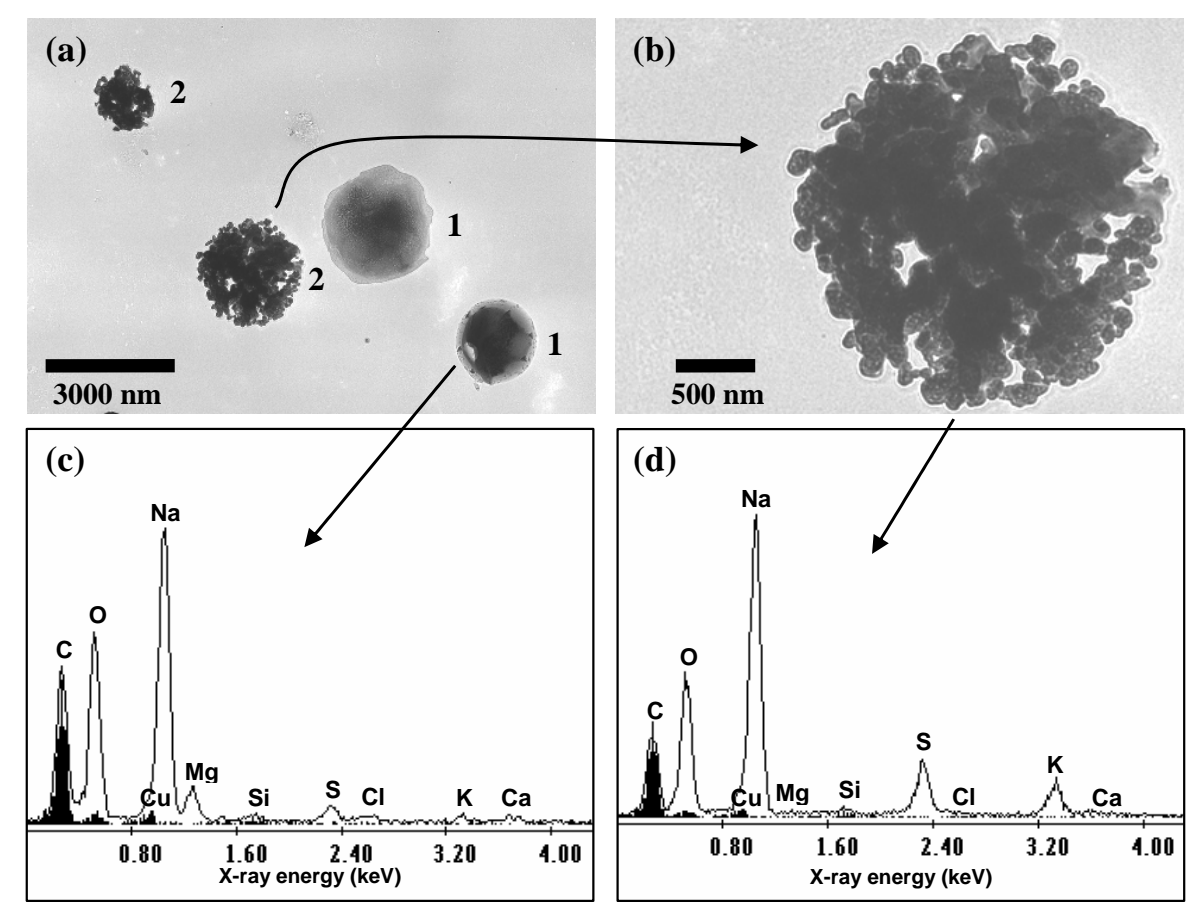

Fig. 11. TEM images of (a1) sea salt particles with strong $\mathrm{Cl}$ depletion and (a2 and b) porous Na-S-K-O-rich particles. The X-ray spectra (c and d) show that porous particle did not contain $\mathrm{Mg}$ and $\mathrm{Ca}$ and that the proportion of $\mathrm{K}$ was high compared to elemental ratios in sea salt (background spectra from TEM grid substrate are depicted with black colour).

contained cation $(\mathrm{Ca}, \mathrm{Mg}$ and/or $\mathrm{K})$ sulphate rims and rods. Images of sea salt particles with similar morphology and composition have been shown in several recent electron microscopy studies (e.g. Ebert et al., 2000; Li et al., 2003a). However, $\mathrm{PM}_{1-3.3}$ sample 10 contained ordinary sea salt particles (36\% of all analysed particles) and also other $\mathrm{Na}-$ rich particles without characteristic morphology and $\mathrm{Mg}-\mathrm{Ca}-$ $\mathrm{K}$ ratios of sea salt (36\% of all analysed particles; Table 4). The morphology of the Na-rich particles was rounded and porous (sponge-like), and they seemed to be composed of numerous, small spherical subparticles (Fig. 11a particles no. 2 and Fig. 11b). They were not very sensitive to beam damage, but under strong intentional beam exposure they were damaged slightly, similarly to sea salt particles. These porous particles contained abundant $\mathrm{Na}$ and $\mathrm{O}$ and some $\mathrm{S}$ and $\mathrm{K}$, while $\mathrm{Mg}$ and $\mathrm{Ca}$ were (almost) totally absent (compare spectra in Fig. 11c and d). Ternary diagrams in Fig. 12 (diagrams in the bottom row) confirm the clearly deviating $\mathrm{Mg}-\mathrm{Ca}-\mathrm{K}$ ratios of these porous particles compared with sea salt particles, although there were also a few (non-porous) sea salt particles with deviating elemental ratios, probably due to inaccuracy in elemental analysis and potentially to the minor presence of fractional recrystallization products of sea salt. The median $\mathrm{Mg} / \mathrm{Na}, \mathrm{K} / \mathrm{Na}$ and $\mathrm{Ca} / \mathrm{Na}$ ratios were $0.131,0.035$ and 0.038 , respectively, for all sea salt particles in $\mathrm{PM}_{1-3.3}$ samples $10-22$, while the corresponding values for Na-S-K-O-rich porous particles were 0.013, 0.141 and
0.004 in $\mathrm{PM}_{1-3.3}$ sample 10. There were also some Na-rich particles with deviating $\mathrm{Mg}-\mathrm{Ca}-\mathrm{K}$ ratios in other samples, but their morphology was never porous.

When water evaporates from seawater droplets, different compounds crystallize separately according to their solubility products (Borchert, 1965; Zayani et al, 1999). After evaporation, sea salt particles may form aggregates of loosely attached crystals that can shatter and produce pure crystals and crystal mixtures (Parungo et al., 1986). Thus, fractional recrystallization may change elemental ratios of sea salt particles in atmosphere and/or during aerosol sampling (Parungo et al., 1986; Ro et al., 2001; Niemi et al., 2005b). However, the porous morphology of Na-S-K-O-rich particles strongly suggests that they were not fractional recrystallization products of sea salt. During their sampling (sample 10 ), air masses had passed over paper industry areas located $\sim 100 \mathrm{~km}$ northeast of Hyytiälä. Large amounts of sodium sulphate $\left(\mathrm{Na}_{2} \mathrm{SO}_{4}\right)$ are used in wood pulp processing, and residuals from these processes are burned. Thus, the burning of mixed sodium sulphate and biomass residuals (contains abundant K) might be the source of Na-S-K-O-rich particles. However, burning of other waste is also a potential source for these particles (Hwang and Ro, 2006), because waste burning is a major source of $\mathrm{Na}$ in continental areas (Ooki et al., 2002). The plentiful presence of aerosols originated from burning sources in sample 10 is also supported by the high proportions of soot and mixed soot/sulphate particles in the 


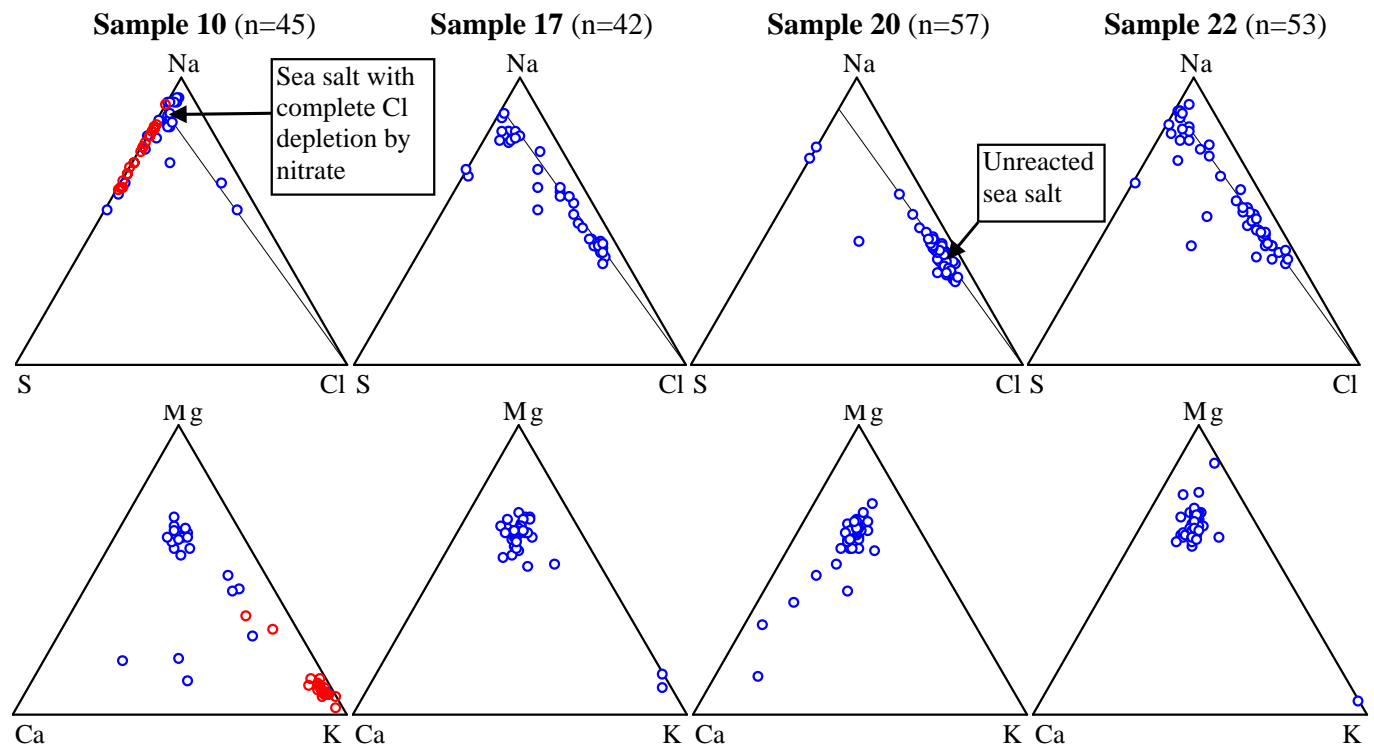

Fig. 12. Ternary diagrams of Cl-Na-S (top row) and $\mathrm{K}-\mathrm{Mg}-\mathrm{Ca}$ (bottom row) ratios for all sea salt particles (blue symbols) and porous Na-S$\mathrm{K}-\mathrm{O}$-rich particles (red symbols) in selected $\mathrm{PM}_{1-3.3}$ samples. The line in $\mathrm{Cl}-\mathrm{Na}-\mathrm{S}$ diagrams depicts the constant $\mathrm{S} / \mathrm{Na}$ ratio, which is the same as in unreacted sea salt particles. When symbols of sea salt particles are located clearly below that line, they indicate substitution of $\mathrm{Cl}$ by S-containing anions such as sulphate or MSA.

$\mathrm{PM}_{0.2-1}$ size fraction (12\% and $22 \%$, respectively, see Table 4) as well as by the elevated $\mathrm{NO}_{2}$ and $\mathrm{NO}$ concentrations (see Table 1 and Fig. 7). The Na-S-K-O-rich particles may have originally contained $\mathrm{Cl}(\mathrm{Na}-\mathrm{Cl} / \mathrm{S}-\mathrm{K}-\mathrm{O}-$ rich particles), but the $\mathrm{Cl}$ substitution by sulphate (or by other acid anions) could have removed it during transport.

During the collection of sample 10, the trajectories curved towards the Arctic Ocean, and in addition to Na-S-K-Orich particles, abundant sea salt particles were present $(37 \%$ in $\mathrm{PM}_{1-3.3}$ sample), as mentioned above. Two hours after the sampling period, the back trajectories reached the Arctic Ocean, and thus, the presence of sea salt particles in sample 10 might indicate a slight inaccuracy in these strongly curved trajectories. A few sea salt particles were also present during the pollution episode (4-9\% in $\mathrm{PM}_{1-3.3}$ samples), but they are not shown in ternary diagrams due to the small amount of particles analysed. The relative proportions of sea salt particles rose especially high during the clean period (67-89\% in $\mathrm{PM}_{1-3.3}$ samples 17-22), when air masses arrived from the direction of the Arctic Ocean. Sea salt particles were also present in $\mathrm{PM}_{3.3-11}$ samples (0-25\%), but in $\mathrm{PM}_{0.2-1}$ samples their abundance was invariably very low (0-3\%).

The rate of $\mathrm{Cl}$ depletion varied strongly between samples (Fig. 12, ternary diagrams of $\mathrm{Cl}-\mathrm{Na}-\mathrm{S}$ ratios in the top row). The proportion of sea salt particles with strong $\mathrm{Cl}$ depletion $(\mathrm{Cl} / \mathrm{Na} \mathrm{X}$-ray count ratio $<0.2)$ was clearly highest $(91 \%)$ in sample 10, while sample 20 contained mainly unreacted sea salt and only a few (4\%) particles with strong $\mathrm{Cl}$ depletion. Samples 17 and 22 contained sea salt particles both with no/minor depletion and with strong $\mathrm{Cl}$ depletion (particles with strong depletion $40 \%$ and $34 \%$, respectively). The main reasons for the especially strong $\mathrm{Cl}$ depletion in sample 10 were probably the long time spent over continent (see trajectory in Fig. 2) and the elevated concentrations of gaseous pollutants. The trajectory of sample 20 clearly stayed the shortest time above the continent before its arrival to Hyytiälä, and the concentrations of gaseous pollutants were very low. This explains well the low rate of $\mathrm{Cl}$ depletion in this sample.

Only a minor fraction of $\mathrm{Cl}$ was replaced with sulphate or MSA in all $\mathrm{PM}_{1-3.3}$ samples since the $\mathrm{S} / \mathrm{Na}$ was almost constant for most of the sea salt particles (Fig. 12, ternary diagrams in the top row). This suggests that $\mathrm{Cl}$ was replaced mainly by $\mathrm{NO}_{3}^{-}$, which is usually the most important $\mathrm{Cl}$-substituting anion together with $\mathrm{SO}_{4}^{2-}$ (Kerminen et al., 1997, 1998). Only a few very small X-ray count peaks for $\mathrm{N}$ were observed in the $\mathrm{X}$-ray spectra due to the insensitivity of EDX to detect $\mathrm{N}$. However, the presence of $\mathrm{NO}_{3}^{-}$ is supported by the bulk chemical results since $\mathrm{NO}_{3}^{-}$and $\mathrm{SO}_{4}^{2-}$ were the most common anions in $\mathrm{PM}_{1.3-10}$ samples (Table 2). The $\mathrm{Cl}$ substitution by nitrate strongly changes the hygroscopic properties of sea salt particles; $\mathrm{NaNO}_{3}$ may contain liquid water at much lower $\mathrm{RH}$ than unreacted sea salt particles (Hoffman et al., 2004). Thus, modification of sea salt particles may change their size, light scattering properties and affinity for CCN formation. The presence of water on sea salt surfaces also greatly enhances their reactivity with gases compared with dry sea salt (ten Brink, 1998; Hara et al., 2002). Furthermore, the nitrate and the non-sea salt $\mathrm{SO}_{4}^{2-}$ that accumulate into sea salt particles are removed 


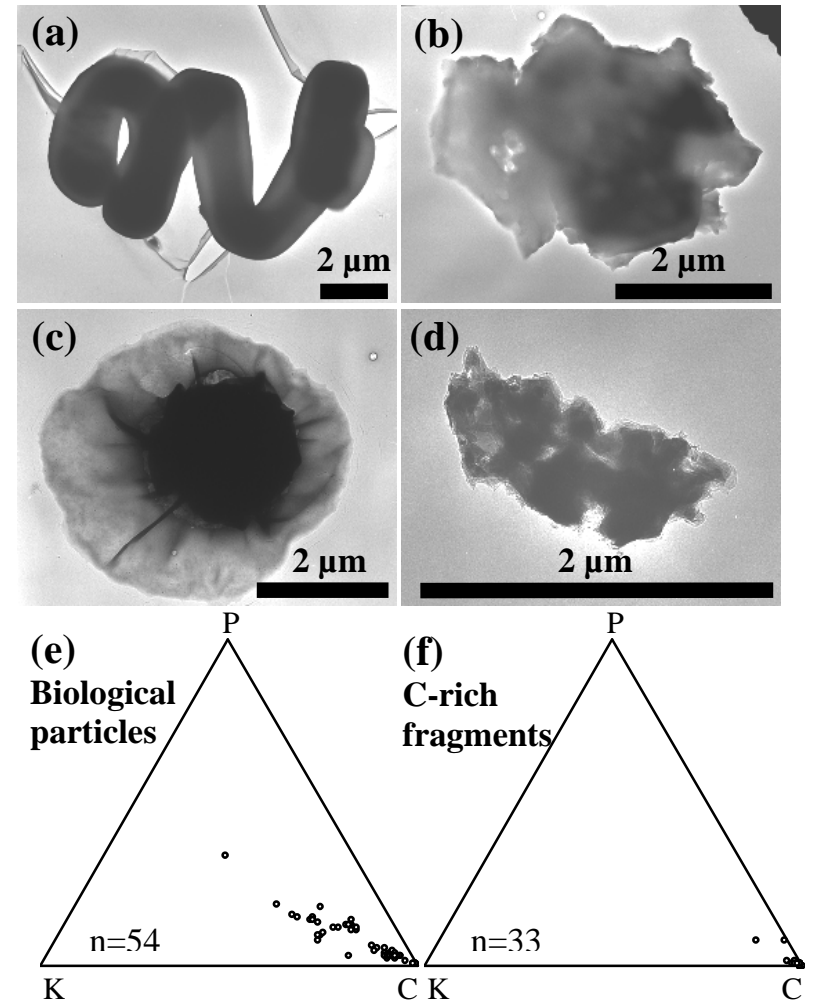

Fig. 13. TEM images of particles classified as (a, c) biological particles and (b, d) C-rich fragments, as well as (e, f) ternary diagrams of C-P-K ratios for these particles from all samples.

rapidly from the atmosphere due to the large sizes of particles, which reduces the amounts of scavenged species in the atmosphere.

\subsubsection{Biological particles and C-rich fragments}

The biological particles contained abundant $\mathrm{C}$, some $\mathrm{O}$ and variable amounts of $\mathrm{K}$ and/or $\mathrm{P}$. Furthermore, a few particles also contained small quantities of $\mathrm{Cl}, \mathrm{S}, \mathrm{Ca}, \mathrm{Mg}, \mathrm{Na}, \mathrm{Si}$ and/or Al. The morphology of these particles varied strongly from spherical and oval to complicated biological structures (Fig. 13a and c). Most of the biological particles were likely spores or conidia of fungi (Wittmaack et al., 2005), but the detailed classification of these particles was beyond the scope of this work. There were also several angular C-rich particles without clearly characteristic morphology of biological particles (Fig. 13b and d), and due to uncertainty in source identification, they were referred to as C-rich fragments. In addition to $\mathrm{C}$, they contained some/minor $\mathrm{O}$, but usually no $\mathrm{P}$ or $\mathrm{K}$. The proportion of particles with detectable $\mathrm{P}$ or $\mathrm{K}$ was only $15 \%$ for C-rich carbon fragments, while the corresponding value for biological particles was $93 \%$ (compare also ternary diagrams for C-P-K ratios in Fig. 13e and f). The TEM images of C-rich fragments were usually quite light (low contrast), which suggests that the fragments were thin. Their appearance and composition further suggest that they might be abrasion products from the surfaces of living or dead organisms. If the C-rich fragments were of biological origin, our observations emphasize that there are abundant biological particles that cannot be detected using only elemental ratios (as used in some computer-controlled SEM/EDX and EPMA studies), and visual observations are needed to separate them from other carbonaceous particles.

The proportions of biological particles and C-rich fragments were highest in the coarse size fraction (in $\mathrm{PM}_{1-3.3}$ samples and especially in $\mathrm{PM}_{3.3-11}$ samples), which is in line with other individual particle studies related to continental background aerosol composition in Northern Europe (Ebert et al., 2000, 2004). No clear difference was observed in the proportions of biological particles and C-rich fragments related to source regions of the air masses. They might originate mainly from local forests, but transport from more distant regions is also possible, as strong changes were seen in the presence of Ca-rich and sea salt particles.

\section{Summary and conclusions}

Aerosol samples were collected at a rural site in southern Finland during polluted, intermediate and clean periods with different origins of particles. The composition, morphology and mixing state of individual particles in three size fractions $\left(\mathrm{PM}_{0.2-1}, \mathrm{PM}_{1-3.3}\right.$ and $\left.\mathrm{PM}_{3.3-11}\right)$ were studied using the TEM/EDX method. TEM/EDX results were complemented with the size-segregated bulk chemical measurements of organic and elemental carbon and selected ions. For more detailed characterization and comparisons, the individual particles analysed were classified into the following 10 groups: 1) tar balls, 2) soot, 3) (ammonium)sulphates and their mixtures with $\mathrm{C}, \mathrm{K}$ and/or different inclusions, 4) silicates, 5) metal oxides/hydroxides, 6) $\mathrm{Ca} / \mathrm{Mg}$ carbonates, sulphates and/or nitrates, 7) sea salt and 8) porous Na-rich particles, 9) biological particles and 10) C-rich fragments.

The composition, morphology and mixing state of particles varied strongly in different size fractions and during different sampling periods, depending on source areas of air masses. During the pollution episode $\left(\mathrm{PM}_{1} \sim 16 \mu \mathrm{g} \mathrm{m}^{-3}\right)$, aerosols originated mainly from polluted areas of Eastern Europe, and some open biomass burning smoke was also brought by long-range transport. The proportions of the following particle types were increased: silicates and metal hydroxides/oxides (included also spherical silicate and metal hydroxide/oxide fly ash particles), $\mathrm{Pb}$-containing particles, tar balls and $\mathrm{Ca} / \mathrm{Mg}$ carbonates/sulphates/nitrates. During the intermediate period $\left(\mathrm{PM}_{1} \sim 5 \mu \mathrm{g} \mathrm{m}^{-3}\right)$, the backward air mass trajectories were short and curving towards the Arctic Ocean, and in $\mathrm{PM}_{1-3.3}$ samples, there were abundant sea salt particles (36\%) with strong $\mathrm{Cl}$ depletion and other porous (sponge-like) Na-rich particles (35\%). The porous Na-rich 
particles contained abundant $\mathrm{S}, \mathrm{K}$ and $\mathrm{O}$, and practically no $\mathrm{Mg}$ and $\mathrm{Ca}$. They might originate from waste burning, especially from the burning of wood pulp wastes of the paper industry, when Na-rich salts $\left(\mathrm{Na}_{2} \mathrm{SO}_{4}\right)$ are used in processes. During the clean period $\left(\mathrm{PM}_{1} \sim 2 \mu \mathrm{g} \mathrm{m}^{-3}\right.$ ), when air masses arrived from the Arctic Ocean, $\mathrm{PM}_{1-3.3}$ samples contained abundant sea salt particles (67-89\%). The rate of $\mathrm{Cl}$ depletion (mainly by $\mathrm{NO}_{3}^{-}$) from sea salt varied markedly depending on the time spent over continent. Strong changes in particle composition were observed in the $\mathrm{PM}_{1-3.3}$ size fraction during the different sampling periods. Thus, not only accumulation mode particles $\left(\mathrm{PM}_{0.2-1}\right)$ but also the finest coarse particles $\left(\mathrm{PM}_{1-3.3}\right)$ may originate mostly from remote sources in clean rural areas.

In $\mathrm{PM}_{0.2-1}$ samples, the major particle groups observed were 1) soot (0-12\%) and 2) (ammonium)sulphates and their mixtures with $\mathrm{C}, \mathrm{K}$, soot inclusions and/or other inclusions (83-97\%). The particles of latter group were divided coarsely into three subgroups; 2a) (ammonium)sulphates mixed with recognizable soot $(2-22 \%), 2 b)$ (ammonium)sulphates mixed with (vacuum-resistant and detectable) carbon (13-36\%) and 2c) (ammonium)sulphates without detectable carbon (26-81\%). Thus, internal mixing of $\mathrm{C}$ and $\mathrm{S}$ was common in particles of $\mathrm{PM}_{0.2-1}$ size fraction. Furthermore, ammonium/sulphate-salts might be more frequently/strongly mixed with (vacuum-resistant) carbonaceous material in aerosols with clearly continental (anthropogenic) origin compared to more marine (clean) origin. The internal mixing of silicates with $\mathrm{S}$ was greater in small particles $\left(\mathrm{PM}_{0.2-1}\right.$ and $\left.\mathrm{PM}_{1-3.3}\right)$ than in larger particles $\left(\mathrm{PM}_{3.3 .-11}\right)$, probably indicating the accumulation of $\mathrm{S}$ during transport. Both $\mathrm{Ca} / \mathrm{Mg}$-rich particles and sea salt particles were strongly mixed with $\mathrm{SO}_{4}^{2-}$ and/or nitrate. The mixing state of particles changes their hygroscopic and optical properties, thus affecting their direct and indirect radiative forcing and their reactivity with gaseous components.

Acknowledgements. The Helsinki University Environmental Research Centre, the Finnish Cultural Foundation and the Academy of Finland (contract no. 201131) are acknowledged for funding this study. We thank our colleagues at the following institutes for their collaboration: P. Aalto, V. Hiltunen, M. Boy and J. Martikainen (Department of Physical Sciences, University of Helsinki), M. Räisänen (The Geological Survey of Finland) and K. Kupiainen (Nordic Envicon Ltd.). The authors gratefully acknowledge the NOAA Air Resources Laboratory (ARL) for provision of the HYSPLIT transport and dispersion model and the READY website (http://www.arl.noaa.gov/ready.html) used in this publication. The Naval Research Laboratory is acknowledged for the NAAPS model results (website at http://www.nrlmry.navy.mil/aerosol).

Edited by: S. Martin

\section{References}

Al-Hosney, H. A. and Grassian, V. H.: Water, sulfur dioxide and nitric acid adsorption on calcium carbonate: A transmission and ATR-FTIR study, Phys. Chem. Chem. Phys., 7, 1266-1276, 2005.

Andreae, M. O.: Soot carbon and excess fine potassium: Longrange transport of combustion derived aerosols, Science, 220, 1148-1151, 1983.

Andreae, M. O., Charlson, R. J., Bruynseels, F., Storms, H., Van Grieken, R., and Maenhaut, W.: Internal mixture of sea salt, silicates, and excess sulfate in marine aerosols, Science, 232, 1620$1623,1986$.

Andreae, M. O., Andreae, T. W., Annegarn, H., Beer, J., Cachier, H., le Canut, P., Elbert, W., Maenhaut, W., Salma, I., Wienhold, F. G., and Zenker, T.: Airborne studies of aerosol emissions from savanna fires in southern Africa: 2. Aerosol chemical composition, J. Geophys. Res., 103, 32 119-32 128, 1998.

Bigg, E. K.: The aerosol in a boreal forest in spring, Tellus B, 53, 510-519, 2001.

Borchert, H.: Principles of oceanic salt deposition and metamorphism, in: Chemical Oceanography, Vol. 2, edited by: Riley, J. P and Skirrow, G., Academic Press, London, pp. 205-276, 1965.

Chakrabarty, R. K., Moosmüller, H., Garro, M. A., Arnott, W. P., Walker, J., Susott, R. A., Babbitt, R. E., Wold, C. E., Lincoln, E. N., and Hao, W. M.: Emissions from the laboratory combustion of wildland fuels: Particle morphology and size, J. Geophys. Res., 111, D07204, doi:10.1029/2005JD006659, 2006.

Chung, S. H. and Seinfeld, J. H.: Climate response of direct radiative forcing of anthropogenic black carbon, J. Geophys. Res., 110, D11102, doi:10.1029/2004JD005441, 2005.

Dall'Osto, M., Beddows, D. C. S., Kinnersley, R. P., Harrison, R. M., Donovan, R. J., and Heal, M. R.: Characterization of individual airborne particles by using aerosol time-of-flight mass spectrometry at Mace Head, Ireland, J. Geophys. Res., 109, D21302, doi:101029/2004JD004747, 2004.

Donaldson, D. J. and Vaida, V.: The influence of organic films at the air-aqueous boundary on atmospheric processes, Chem. Rev., 106, 1445-1461, 2006.

Draxler, R. R. and Rolph, G. D.: HYSPLIT (HYbrid Single-Particle Lagrangian Integrated Trajectory), Model access via NOAA ARL READY Website (http://www.arl.noaa.gov/ready/hysplit4. html), NOAA Air Resources Laboratory, Silver Spring, MD., 2003.

Ebert, M., Weinbruch, S., Hoffmann, P., and Ortner, H. M.: Chemical characterization of North Sea aerosol particles, J. Aerosol. Sci., 31, 613-632, 2000.

Ebert, M., Weinbruch, S., Rausch, A., Gorzawski, G., Hoffmann, P., Wex, H., and Helas, G.: Complex refractive index of aerosols during LACE 98 as derived from the analysis of individual particles, J. Geophys. Res., 107, 8121, doi:10.1029/2000JD000195, 2002.

Ebert, M., Weinbruch, S., Hoffmann, P., and Ortner, H. M.: The chemical composition and complex refractive index of rural and urban influenced aerosols determined by individual particle analysis, Atmos. Environ., 38, 6531-6545, 2004.

EMEP: Transboundary acidification and eutrophication and ground level ozone in Europe. Joint CIAM \& CCC \& MSC-W report, EMEP Summary Report 1/2001, 2001. 
EMEP: Transboundary particulate matter in Europe: Status Report 2002, EMEP Report 5/2002, 89 pp, 2002.

Hand, J. L., Malm, W. C., Laskin, A., Day, D., Lee, T., Wang, C., Carrico, C., Carrillo, J., Cowin, J. P., Collett, J., and Iedema, M. J.: Optical, physical, and chemical properties of tar balls observed during the Yosemite Aerosol Characterization Study, J. Geophys. Res., 110, D21210, doi:10.1029/2004JD005728, 2005.

Hara, K., Osada, K., Nishita, C., Yamagata, S., Yamanocuhi, T., Herber, A., Matsunaga, K., Iwasaka, Y., Nagatani, M., and Nakata, H.: Vertical variations of sea-salt modification in the boundary layer of spring Arctic during the ASTAR 2000 campaign, Tellus B, 54, 361-376, 2002.

Häsänen, E., AunelaTapola, L., Kinnunen, V., Larjava, K., Mehtonen, A., Salmikangas, T., Leskelä, J., and Loosaar, J.: Emission factors and annual emissions of bulk and trace elements from oil shale fueled power plants, Sci. Total Environ., 198, 1-12, 1997.

Hasegawa, S. and Ohta, S.: Some measurements of the mixing state of soot-containing particles at urban and non-urban sites, Atmos. Environ., 36, 3899-3908, 2002.

Held, A., Hinz, K. P., Trimborn, A., Spengler, B., and Klemm, O.: Chemical classes of atmospheric aerosol particles at a rural site in Central Europe during winter, J. Aerosol. Sci., 33, 581-594, 2002.

Hinz, K. P., Trimborn, A., Weingartner, E., Henning, S., Baltensperger, U., and Spengler, B.: Aerosol single particle composition at the Jungfraujoch, J. Aerosol. Sci., 36, 123-145, 2005.

Hoffman, R. C., Laskin, A., and Finlayson-Pitts, B. J.: Sodium nitrate particles: physical and chemical properties during hydration and dehydration, and implications for aged sea salt aerosols, J. Aerosol. Sci., 35, 869-887, 2004.

Hoornaert, S., Van Malderen, H., and Van Grieken, R.: Gypsum and other calcium-rich aerosol particles above the North Sea, Environ. Sci. Technol., 30, 1515-1520, 1996.

Hwang, H. and Ro, C.-U.: Single-particle characterization of municipal solid waste (MSW) ash particles using low-Z particle electron probe X-ray microanalysis, Atmos. Environ., 40, 28732881, 2006.

IPCC: Climate Change 2001 - The Scientific Basis, Cambridge University Press, New York, 289-348, 2001.

Jalkanen, L., Makinen, A., Häsänen, E., and Juhanoja, J.: The effect of large anthropogenic particulate emissions on atmospheric aerosols, deposition and bioindicators in the eastern Gulf of Finland region, Sci. Total Environ., 262, 123-136, 2000.

Johnson, K. S., Zuberi, B., Molina, L. T., Molina, M. J., Iedema, M. J., Cowin, J. P., Gaspar, D. J., Wang, C., and Laskin, A.: Processing of soot in an urban environment: case study from the Mexico City Metropolitan Area, Atmos. Chem. Phys., 5, 30333043, 2005, http://www.atmos-chem-phys.net/5/3033/2005/.

Kanakidou, M., Seinfeld, J. H., Pandis S. N., et al.: Organic aerosol and global climate modelling: a review, Atmos. Chem. Phys, 5, 1053-1123, 2005.

Karppinen, A., Härkönen, J., Kukkonen, J., Aarnio, P., and Koskentalo, T.: Statistical model for assessing the portion of fine particulate matter transported regionally and long range to urban air, Scandinavian Journal of Work, Environment \& Health, 30, 4753, 2004.

Kerminen, V.-M., Pakkanen, T. A., and Hillamo, R. E.: Interactions between inorganic trace gases and supermicrometer particles at a coastal site, Atmos. Environ., 31, 2753-2765, 1997.

Kerminen, V.-M., Teinilä, K., Hillamo, R., and Pakkanen, T.: Substitution of chloride in sea-salt particles by inorganic and organic anions, J. Aerosol. Sci., 29, 929-942, 1998.

Kocbach, A., Johansen, B. V., Schwarze, P. E., and Namork, E.: Analytical electron microscopy of combustion particles: a comparison of vehicle exhaust and residential wood smoke, Sci. Total Environ., 346, 231-243, 2005.

Kojima, T., Buseck, P. R., Wilson, J. C., Reeves, J. M., and Mahoney, M. J.: Aerosol particles from tropical convective systems: Cloud tops and cirrus anvils, J. Geophys. Res., 109, D12201, doi:10.1029/2003JD004504, 2004.

Kojima, T., Buseck, P. R., and Reeves, J. M.: Aerosol particles from tropical convective systems: 2. Cloud bases, J. Geophys. Res., 110, D09203, doi:10.1029/2004JD005173, 2005.

Kulmala, M., Hämeri, K., Aalto, P.P., Mäkelä, J. M., Pirjola, L., Nilsson, E. D., Buzorius, G., Rannik, Ü., Dal Maso, M., Seidl, W., Hoffman, T., Janson, R., Hansson, H. C., Viisanen, Y., Laaksonen, A., and O'Dowd, C. D.: Overview of the international project on biogenic aerosol formation in the boreal forest (BIOFOR), Tellus B, 53, 324-343, 2001.

Laakso, L., Hussein, T., Aarnio, P., Komppula, M., Hiltunen, V., Viisanen, Y., and Kulmala, M.: Diurnal and annual characteristics of particle mass and number concentrations in urban, rural and Arctic environments in Finland, Atmos. Environ., 37, 26292641, 2003.

Laskin, A., Iedema, M. J., Ichkovich, A., Graber, E. R., Taraniuk, I., and Rudich, Y.: Direct observation of completely processed calcium carbonate dust particles, Faraday Discuss., 130, 453468, 2005a.

Laskin, A., Wietsma, T. W., Krueger, B. J., and Grassian, V. H.: Heterogeneous chemistry of individual mineral dust particles with nitric acid: A combined CCSEM/EDX, ESEM, and ICP-MS study, J. Geophys. Res., 110, D10208, doi:10.1029/2004JD005206, 2005b.

Laskin, A., Cowin, J. P., and Iedema, M. J.: Analysis of individual environmental particles using modern methods of electron microscopy and X-ray microanalysis, Journal of Electron Spectroscopy and Related Phenomena, 150, 260-274, 2006.

Lee, D. S. and Pacyna, J. M.: An industrial emissions inventory of calcium for Europe, Atmos. Environ., 33, 1687-1697, 1999.

Lee, S. H., Murphy, D. M., Thomson, D. S., and Middlebrook, A. M.: Chemical components of single particles measured with Particle Analysis by Laser Mass Spectrometry (PALMS) during the Atlanta SuperSite Project: Focus on organic/sulfate, lead, soot, and mineral particles, J. Geophys. Res., 107(D1), 4003, doi:10.1029/2000JD000011, 2002.

Li, J., Anderson, J. R., and Buseck, P. R.: TEM study of aerosol particles from clean and polluted marine boundary layers over the North Atlantic, J. Geophys. Res., 108, 4189, doi:10.1029/2002JD002106, 2003a.

Li, J., Pósfai, M., Hobbs, P. V., and Buseck, P. R.: Individual aerosol particles from biomass burning in southern Africa: 2, Compositions and aging of inorganic particles, J. Geophys. Res., 108, 8484, doi:10.1029/2002JD002310, 2003b.

Liu, X. D., Van Espen, P., Adams, F., Cafmeyer, J., and Maenhaut, W.: Biomass burning in southern Africa: Individual particle characterization of atmospheric aerosols and savanna fire samples, J. Atmos. Chem., 36, 135-155, 2000. 
Liu, X. H., Penner, J. E., and Herzog, M.: Global modeling of aerosol dynamics: Model description, evaluation, and interactions between sulfate and nonsulfate aerosols, J. Geophys. Res., 110, D18206, doi:101029/2004JD005674, 2005.

Loo, B. W. and Cork, C. P.: Development of high-efficiency virtual impactors, Aerosol Sci. Technol., 9, 167-176, 1988.

Mitchell, R. I. and Pilcher, J. M.: Improved cascade impactor for measuring aerosol particle sizes, Industrial and Engineering Chemistry, 51, 1039-1042, 1959.

Niemi, J. V., Tervahattu, H., Vehkamäki, H., Kulmala, M., Koskentalo, T., Sillanpää, M., and Rantamäki, M.: Characterization and source identification of a fine particle episode in Finland, Atmos. Environ., 38, 5003-5012, 2004.

Niemi, J. V., Tervahattu, H., Vehkamäki, H., Martikainen, J., Laakso, L., Kulmala, M., Aarnio, P., Koskentalo, T., Sillanpää, M., and Makkonen, U.: Characterization of aerosol particle episodes in Finland caused by wildfires in Eastern Europe, Atmos. Chem. Phys, 5, 2299-2310, 2005a.

Niemi, J. V., Tervahattu, H., Virkkula, A., Hillamo, R., Teinilä, K., Koponen, I. K., and Kulmala, M.: Continental impact on marine boundary layer coarse particles on Atlantic Ocean between Europe and Antarctica, Atmos. Res., 75, 301-321, 2005b.

Okada, K., Ikegami, M., Zaizen, Y., Tsutsumi, Y., Makino, Y., Jensen, J. B., and Gras, J. L.: Soot particles in the free troposphere over Australia, Atmos. Environ., 39, 5079-5089, 2005.

Ooki, A., Uematsu, M., Miura, K., and Nakae, S.: Sources of sodium in atmospheric fine particles, Atmos. Environ., 36, 43674374, 2002.

Pakkanen, T. A., Loukkola, K., Korhonen, C. H., Aurela, M., Makela, T., Hillamo, R. E., Aarnio, P., Koskentalo, T., Kousa, A., and Maenhaut, W.: Sources and chemical composition of atmospheric fine and coarse particles in the Helsinki area, Atmos. Environ., 35, 5381-5391, 2001.

Parungo, F. P., Nagamoto, C. T., and Harris, J. M.: Temporal and spatial variations of marine aerosols over the Atlantic Ocean, Atmos. Res., 20, 23-37, 1986.

Pósfai, M., Anderson, J. R., Buseck, P. R., and Sievering, H.: Soot and sulfate aerosol particles in the remote marine troposphere, $\mathrm{J}$. Geophys. Res., 104, 21 685-21 693, 1999.

Pósfai, M. and Molnár, A.: Aerosol particles in the troposphere: a mineralogical introduction, in: Environmental Mineralogy, European Mineralogical Union Notes in Mineralogy, Vol. 2, edited by: Vaughan, D. and Wogelius, R., Eötvös Unversity Press, Budapest, pp. 197-252, 2000.

Pósfai, M., Simonics, R., Li, J., Hobbs, P. V., and Buseck, P. R.: Individual aerosol particles from biomass burning in southern Africa: 1. Compositions and size distributions of carbonaceous particles, J. Geophys. Res., 108, 8483, doi:10.1029/2002JD002291, 2003.

Pósfai, M., Gelencser, A., Simonics, R., Arato, K., Li, J., Hobbs, P. V., and Buseck, P. R.: Atmospheric tar balls: Particles from biomass and biofuel burning, J. Geophys. Res., 109, D06213, doi:10.1029/2003JD004169, 2004.

Ricard, V., Jaffrezo, J. L., Kerminen, V. M., Hillamo, R. E., Sillanpää, M., Ruellan, S., Liousse, C., and Cachier, H.: Two years of continuous aerosol measurements in northern Finland, J. Geophys. Res., 107, 4129, doi:10.1029/2001JD000952, 2002.

Ro, C. U., Oh, K. Y., Kim, H., Kim, Y. P., Lee, C. B., Kim, K. H., Kang, C. H., Osan, J., De Hoog, J., Worobiec, A., and Van
Grieken, R.: Single-particle analysis of aerosols at Cheju Island, Korea, using low-Z electron probe X-ray microanalysis: A direct proof of nitrate formation from sea salts, Environ. Sci. Technol., 35, 4487-4494, 2001.

Ro, C.U., Hwang, H., Chun, Y., and Van Grieken, R.: Singleparticle characterization of four "Asian Dust" samples collected in Korea, using low-Z particle electron probe X-ray microanalysis. Environ. Sci. Technol., 39, 1409-1419, 2005.

Rolph, G. D.: Real-time Environmental Applications and Display sYstem (READY) Website (http://www.arl.noaa.gov/ready/ hysplit4.html), NOAA Air Resources Laboratory, Silver Spring, MD., 2003.

Ruoho-Airola, T., Anttila, P., and Salmi, T.: Airborne sulfur and nitrogen in Finland - trends and exposure in relation to air transport sector, J. Environ. Monit., 6, 1-11, 2004.

Saarikoski, S., Mäkelä, T., Hillamo, R., Aalto, P. P., Kerminen, V.-M., and Kulmala, M.: Physico-chemical characterization and mass closure of size-segregated atmospheric aerosols in Hyytiälä, Finland, Boreal Env. Res., 10, 385-400, 2005.

Schnaiter, M., Linke, C., Möhler, O., Naumann, K.H., Saathoff, H., Wagner, R., Schurath, U., and Wehner, B.: Absorption amplification of black carbon internally mixed with secondary organic aerosol, J. Geophys. Res., 110, D19204, doi:10.1029/2005JD006046, 2005.

Sillanpää, M., Saarikoski, S., Hillamo, R., Pennanen, A., Makkonen, U., Spolnik, Z., Van Grieken, R., Koskentalo, T., and Salonen, R. O.: Chemical composition, mass size distribution and source analysis of long-range transported wildfire smokes in Helsinki, Sci. Total Environ., 350, 119-135, 2005.

Simoneit, B. R. T., Schauer, J. J., Nolte, C. G., Oros, D. R., Elias, V. O., Fraser, M. P., Rogge, W. F., and Cass, G. R.: Levoglucosan, a tracer for cellulose in biomass burning and atmospheric particles, Atmos. Environ., 33, 173-182, 1999.

Sogacheva, L., Dal Maso, M., Kerminen, V.-M., and Kulmala, M.: Probability of nucleation events and aerosol particle concentration in different air mass types arriving at Hyytiälä, southern Finland, based on back trajectories analysis, Boreal Env. Res., 10, 479-491, 2005.

Song, C. H. and Carmichael, G. R.: The aging process of naturally emitted aerosol (sea-salt and mineral aerosol) during long range transport, Atmos. Environ., 33, 2203-2218, 1999.

Sun, J. and Ariya, P. A.: Atmospheric organic and bio-aerosols as cloud condensation nuclei $(\mathrm{CCN})$ : A review, Atmos. Environ., 40, 795-820, 2006.

Tang, I. N. and Fung, K. H.: Hydration and Raman scattering studies of levitated microparticles: $\mathrm{Ba}\left(\mathrm{NO}_{3}\right)_{2}, \mathrm{Sr}\left(\mathrm{NO}_{3}\right)_{2}$, and $\mathrm{Ca}\left(\mathrm{NO}_{3}\right)_{2}$, J. Chem. Phys., 106, 1653-1660, 1997.

ten Brink, H. M.: Reactive uptake of $\mathrm{HNO}_{3}$ and $\mathrm{H}_{2} \mathrm{SO}_{4}$ in sea-salt $(\mathrm{NaCl})$ particles, J. Aerosol. Sci., 29, 57-64, 1998.

Tervahattu, H., Hongisto, M., Aarnio, P., Kupiainen, K., and Sillanpää, M.: Composition and origins of aerosol during a high PM $_{10}$ episode in Finland, Boreal Env. Res., 9, 335-345, 2004.

Tervahattu, H., Juhanoja, J., Vaida, V., Tuck, A. F., Niemi, J. V., Kupiainen, K., Kulmala, M., and Vehkamäki, H.: Fatty acids on continental sulfate aerosol particles, J. Geophys. Res., 110, D06207, doi:10.1029/2004JD005400, 2005.

Tunved, P., Nilsson, E. D., Hansson, H. C., Strom, J., Kulmala, M., Aalto, P., and Viisanen, Y.: Aerosol characteristics of air masses in northern Europe: Influences of location, 
transport, sinks, and sources, J. Geophys. Res., 110, D07201 doi:10.1029/2004JD005085, 2005.

Vallius, M., Lanki, T., Tiittanen, P., Koistinen, K., Ruuskanen, J., and Pekkanen, J.: Source apportionment of urban ambient $\mathrm{PM}_{2.5}$ in two successive measurement campaigns in Helsinki, Finland, Atmos. Environ., 37, 615-623, 2003.

van Poppel, L. H., Friedrich, H., Spinsby, J., Chung, S. H., Seinfeld, J. H., and Buseck, P. R.: Electron tomography of nanoparticle clusters: Implications for atmospheric lifetimes and radiative forcing of soot, Geophys. Res. Lett., 32, L24811, doi:10.1029/2005GL024461, 2005.

WHO: Health aspects of air pollution with particulate matter, ozone and nitrogen dioxide. Working group report, 13-15 January 2003, World Health Organization, Bonn, 2003.

Wittmaack, K., Wehnes, H., Heinzmann, U., and Agerer, R.: An overview on bioaerosols viewed by scanning electron microscopy, Sci. Total Environ., 346, 244-255, 2005.
Zayani, L., Rokbani, R., and Trablesi-Ayedi, M.: Study of the evaporation of a brine involving the system $\mathrm{Na}^{+}, \mathrm{Mg}^{2+}, \mathrm{K}^{+}$, $\mathrm{Cl}^{-}, \mathrm{SO}_{4}^{2}-\mathrm{H}_{2} \mathrm{O}-$ Crystallisation of oceanic salts, J. Therm. Anal. Calorim., 57, 575-585, 1999.

Zhang, Q., Canagaratna, M. R., Jayne, J. T., Worsnop, D. R., and Jimenez, J. L.: Time- and size-resolved chemical composition of submicron particles in Pittsburgh: Implications for aerosol sources and processes, J. Geophys. Res., 110, D07S09, doi:10.1029/2004JD004649, 2005.

Zuberi, B., Johnson, K. S., Aleks, G. K., Molina, L. T., and Laskin, A.: Hydrophilic properties of aged soot, Geophys. Res. Lett., 32, L01807, doi:10.1029/2004GL021496, 2005. 